\title{
The Limited Partnership Model in Private Equity: Deal Returns over a Fund's Life
}

\author{
Reiner Braun \\ Friedrich-Alexander University, Erlangen-Nuremberg \\ Maximilian Schmidt \\ Technische Universität München, Munich ${ }^{*}$
}

January 2014

\begin{abstract}
Private equity (PE) fund managers recurrently close limited partnerships, thereby running several funds simultaneously. Conceptually, the limited partnership model as a form of financial intermediation should not have any impact on decisions about single PE investments and returns. This study takes advantage of a unique database containing cash flow data on 10,566 investments by $702 \mathrm{PE}$ limited partnerships. We note a robust drop in investment returns once a new limited partnership is established. This pattern has increasingly emerged since the late-1990s. We conclude that the current governance form of limited partnership model is of questionable benefit in a matured PE industry
\end{abstract}

Keywords: Financial intermediation, private equity, limited partnership, returns

JEL Classification: G11, G20

\footnotetext{
* Contact information: Reiner Braun, reiner.braun@fau.de; +49-911-5302-684; Friedrich-Alexander Universität Erlangen-Nürnberg; Lange Gasse 20, 90403 Nürnberg, Germany and Maximilian Schmidt; maximilian.schmidt@wi.tum.de.
} 


\section{Introduction}

In the private equity (PE) asset class, closed-end fund structures are the dominant form of financial intermediation. In 2012, worldwide capital under management in the PE industry made up for more than two trillion US dollar. However, more recently, more and more doubts have arisen as to whether building special-purpose vehicles as closed-end limited partnerships as a form of intermediation to gather funds to invest equity in private companies is the right form of governance. Typically, as general partners (GPs) of such limited partnerships, PE fund managers raise capital from institutional investors as limited partners (LPs) to build a new limited partnership every three to five years. From the PE fund managers' perspective, a new fund ensures the permanent availability of capital to invest and a guaranteed income stream from nonperformance-related management fees paid by LPs. Hence, PE fund managers have a recurring incentive to demonstrate quality as a financial intermediary every time they raise a new fund. If this situation results in divestment decisions to the current fund investor's detriment, it represents a major agency problem stemming from the current form of financial intermediation in the PE asset class (e.g. Metrick and Yasuda, 2010). Whether the limited partnership model is associated with such problems is of utmost interest to investors in the maturing PE asset class. However, convincing large-scale empirical evidence in this issue is scarce at best and previous research provides inconclusive results (e.g. Chung et al., 2012, Metrick and Yasuda, 2010.).

In this paper, we take advantage of a novel proprietary data set combining detailed information on more than 10,000 realized investments by 702 corresponding venture capital (VC) and buyout limited partnerships over the last 40 years to investigate whether the limited partnership governance model in its current form has an impact on investment returns. For both VC and buyout funds, we find that deal returns vary strongly over a limited partnership's life. More specifically, we provide robust evidence that returns to investments realized when a new limited partnership is raised are significantly higher than for investments exited after such a new fund is closed. We relate this finding to potential window-dressing behaviour of PE fund managers ${ }^{1}$. We also show that this phenomenon is much more pronounced for $\mathrm{VC}$ funds and

\footnotetext{
${ }^{1}$ Window dressing is a term used to describe the act of making a company's or fund's performance look attractive. There is a controversial discussion in the research on financial intermediation concerning the empirical evidence of
} 
emerged at the end of the 1990s, during the proliferation of fundraising and substantial drop in PE returns, a situation that has prevailed ever since. By analysing underpricing of PE-sponsored initial public offerings (IPO), we provide evidence that this return pattern represents a moral hazard issue between fund managers and their investors in limited partnerships for VC funds, but not buyout funds. We conclude that in $\mathrm{VC}$, as a major part of the PE asset class, limited partnerships in their current form are not suitable to align the interests of GPs and LPs.

Over the last years, discontent has grown among investors in the PE asset class. As GPs, PE firms have been unable to provide decent (Sensoy et al., 2013) and persistent returns (Braun et al., 2013; Harris et al., 2013) to institutional investors LPs in PE limited partnerships over the last ten to 15 years. Many of these investors have raised doubts as to whether the PE industry is just going through a normal cycle and will return to past net return levels (Kaplan and Lerner, 2009); instead, they have started to question the coherence of the current financial intermediation methods of PE investing (Mulcahy et al., 2012).

There are at least two related controversial debates. First, there is the debate on whether closed-end limited partnerships are necessarily the right form of governance for PE funds. For some investments, particularly in the early stages of a company's life, a fund lifetime of ten to 12 years could simply be too short to take advantage of an investment's full potential (Kandel et al., 2011; Lerner, 2012). Further, since PE firms as GPs can make investments only during the first five to six years after closing the partnership, they raise new funds every three to five years to ensure their permanent ability to invest in promising targets (Chung et al., 2012; Gompers and Lerner, 1999). But fundraising activities absorb a substantial amount of their time and could create agency problems, since they need to serve different investors with interests in different funds once a follow-on partnership is raised (Metrick and Yasuda, 2010).

In this context, the second, related concern raised by many LPs is that, given increasing fund sizes, the GP compensation scheme of these limited partnerships is not ideal (anymore) to align the interests of investors and fund managers. Because non-performance-related management fees were kept nearly stable over time while fund sizes have steadily grown, the relative shares of these fees in fund managers' total compensation have become increasingly high, leaving investors to wonder whether PE firms are still incentivized to create decent returns

actual window dressing behavior. The literature covers different asset classes, most often equity and bond mutual funds (Lakonishok et al., 1991; Morey and O’Neal, 2006; Musto, 1997). 
(Metrick and Yasuda, 2010). The proliferation of fundraising, fuelled by this incentive to close large funds guaranteeing income from fees, has created a situation in which too much money is chasing too few deals, resulting in low net returns (Gompers and Lerner, 2000).

While this debate on the changing GP-LP relationship and corresponding shift in its power dynamic has been going on for years, the basic form of financial governance has not changed. A notable recent exception is Altas Partners, founded in 2012 by Andrew Sheiner, a former partner at Onex Corporation. Altas Partners addresses the need to realign the interests of fund managers and their investors by offering the latter the option for long-term ownership beyond a limited lifetime of ten years. The explicit reason is to break through fundraising cycles. However, Altas Partners is a rare, if not unique, example and most funds raised now are still structured as classic closed-end limited partnerships. This situation calls for further examination of financial intermediation in the PE asset class.

From a market perspective, the current form of financial intermediation would be optimal if every dollar invested by investors into closed-end limited partnerships were optimally put to work by PE fund managers as financial intermediaries. However, limited partnerships are just a legal wrapper governing single investments in private companies. Ultimately, the crucial question is therefore whether investment decisions at the deal level yield good returns for investors (Braun et al., 2013). While the vast majority of previous studies examine limited partnership returns as an entity (see, e.g. Phalippou and Gottschalg, 2009; Robinson and Sensoy, 2013), we combine this perspective with the single investment level: To analyse the appropriateness of financial intermediation in the PE asset class, we investigate deal-level returns over a fund's life. It is our null hypothesis that the governance model of a closed-end limited partnership has no influence on single deal returns. If the current model is an appropriate form of financial intermediation, there is no reason to believe that single investment returns vary over a fund's life beyond other explanatory factors such as market cycles. Hence, our main dependent variable is a fund's relative deal performance measure, which sets each investment's return in relation to the overall return of the limited partnership through which it was made (i.e. an intra-fund return variation measure at the single investment level). Assume, for example a fund yields a return of 2.0 public market equivalents (PMEs) to its investors at fund maturity. One of the single investments that finally led to this fund performance yielded a single deal PME of 2.5. Hence, our fund's relative deal score is $0.25(=(2.5-2.0) / 2=0.25)$, which indicates that this investment's performance was 
$25 \%$ higher than the final fund performance. In contrast to absolute returns, this relative measure rules out patterns over the course of a fund's life being simply an artefact of good PE firms in our sample exiting deals earlier in a limited partnership's lifetime. Thus, under the null hypothesis's assumption, this relative measure should undergo no significant structural changes over a fund's life.

In turn, if a structural pattern of varying returns over a fund's life exists, it should be driven by the fund manager's incentives to make certain decisions at the investment level induced by the governance form of closed-end limited partnerships. To put this hypothesis to a test, we distinguish between investments realized before a follow-on fund is closed by the same PE firm and those deals exited during the remaining time of a limited partnership's life. We think that these two stages of a fund's life differ fundamentally in terms of the incentives stemming from the limited partnership governance model. From a GP's perspective, the first years of a limited partnership's life are characterized by investing the committed capital into appropriate private companies. Since investment activity is limited to only the first five to six years of a limited partnership, the governance model requires PE managers to raise a new fund after five to six years at the latest if they want to continue investing.

Probably even more importantly, fees from LPs to GPs are often reduced after this initial investment period. Hence, there is a strong incentive for the PE firm to create a continuous income stream through non-performance-related fees by raising a follow-on fund before the investment period of the current limited partnership ends (Metrick and Yasuda, 2010). Indeed, on average, PE firms raise a new fund every three years (Chung et al., 2012). Potential investors considering committing money to a new limited partnership (a follow-on fund) strongly emphasize the most recent evidence of a fund manager's capability, that is the track record of the most recent deals from the current fund (Kaplan and Schoar, 2005). In this regard, most investors will prefer externally validated returns from realized investments over the mark-to-market values of yet unrealized companies still in the current limited partnership's portfolio, since these valuations are reliable only to a certain extent (Brown et al., 2013, Jenkinson et al., 2013).

Therefore, we argue that before a follow-on fund is closed, there is good reason for fund managers to realize investments, sending positive signals to potential LPs of a follow-on fund early on in the current fund's life. It is rational for a PE firm to maximize its income from all the limited partnerships it manages (Chung et al., 2012). Hence, the PE firm has a strong interest in 
raising a new large fund that ensures an income stream from management fees typically directly related to fund size. If this incentive to support fundraising activities results in structurally lower relative returns after a follow-on fund is closed, indicating that the PE firm leaves money on the table to the detriment of LPs in the current fund, this represents a moral hazard issue between the PE firm as the GP of the limited partnership and its LPs in the current limited partnership. This is the issue we investigate in this paper. If we find a robust pattern of substantially reduced investment returns after a follow-on fund is raised, we have to reject the null hypothesis and can conclude that the current governance model has a negative impact on investors in the PE asset class. We provide a set of analyses and robustness tests to analyse this overarching question of financial intermediation in the PE asset class.

To the best of our knowledge, our paper is the first to focus in on the limited partnership and the distribution of investment returns over the life of a fund, bridging both levels, the deal and fund levels, of the analysis. We take advantage of a new, proprietary data set of more than 10,000 realized deals by about 700 buyout and VC partnerships over more than 30 years. We obtained this remarkable (in terms of both size and level of granularity) proprietary data set from three large fund of funds (FoF) investors that were LPs in many limited partnerships. Whenever a PE firm in the buyout or VC market tried to build a new partnership and asked one of the three institutional investors to commit money, they had to provide a complete track record of previous investments and funds. Altogether, our initial data set contains almost 24,000 investments by about 1,400 buyout and VC funds.

However, we restrict this initial sample to analyse deal returns over a fund's life. All the funds we consider in this study are mature; and we therefore have a good picture of the distribution of returns over fund age and can observe the complete portfolio of investments and their deal-level gross monthly cash flows. We also have information at the deal level, such as investment size, industry, and region, and at the fund level, such as the first and last investments and fund size. Further, we know which PE firm managed the fund and to which family of funds it belonged so that we can exactly identify the follow-on fund and its final closing date. This enables us to obtain a comprehensive understanding of investment and divestment patterns, particularly where the limited partnership stood when a single deal was realized. Bridging these two levels allows us to carry out the first study on the effects of fund dynamics on investment returns. 
Having deal-level gross cash flows also comes with the advantage that we can compute exact measures of deal performance. Our data set contains original cash flows between portfolio companies and limited partnerships. Hence, our analysis of the variation in deal returns over a fund's life is not blurred by the compensation structure of the limited partnership and we have a clear view of what was really earned with each investment. Further, monthly cash flows allow us to calculate PMEs alongside already established measures of performance such as internal rates of return (IRRs) and money multiples. A deal's PME gives the performance of the investment relative to an alternative investment in the stock market over the same period of time. Our analysis focuses particularly on PMEs for two main reasons: First, other scholars have brought up convincing arguments why a PME is a more relevant measure for investors in the asset class (see, e.g. Kaplan and Schoar, 2005). Second, IRRs, still the dominant performance measure, are almost by definition higher in the early years of a fund's life, since the holding periods are much shorter then. Consider, for example an investment of 100 that yields a return of 110. If the investment is realized after one year, the IRR is $10 \%$. If the same payback is realized after the investment is held for two years, the IRR is reduced to about 5\%. Now, in our analysis of investment returns over a fund's life, deals exited early in a limited partnership's life are much more likely to have a shorter holding period and would, therefore, almost naturally yield higher IRRs. Therefore, we turn to PMEs when analysing returns over a fund's life. We use the three regional MSCI Performance Indices (North America, Europe, and Asia) in local currency as benchmarks for our calculations and the regional index where the fund manager is located.

Another advantage of having this level of information is that it enables us to restrict the sample to only realized deals, thereby circumventing various problems associated with unrealized or partially unrealized investments. Recent studies show that the valuations of companies still held in the portfolios of buyout and VC funds are inflated in times of fundraising (Brown et al., 2013; Jenkinson et al., 2013). Therefore, including unrealized investments based on valuations would cause the problem of comparing apples (real returns to exited investments) to oranges (valuations of unrealized or partially realized investments). While our sample contains only mature funds, some of them still have unrealized or only partially realized investments in their portfolios..

Our first main finding is that absolute deal returns indeed vary strongly over a PE limited partnership's life. Investments realized after two or three years yield the highest deal PMEs and 
IRRs. However, only few deals are exited early on. After these exceptional investments are exited, the fourth and fifth years of a fund's life witness an increasing number of realizations with poor returns. The remaining portfolio of investments realized between year six and fund maturity yields mediocre returns that lie between the poor performance in years four and five and the exceptional returns in the second and third years. Our analysis also shows a considerable number of exits after the tenth and even the 12th year. We find the variation in deal returns over a fund's life to be stronger for $\mathrm{VC}$ funds than for buyout funds. This finding is in line with the highrisk/return profile of VC investing (Cochrane, 2005). This pattern of returns over a fund's life holds for absolute returns, as well as for our fund's relative deal performance measure. We then show that it also holds in a multivariate setting, using fund relative PME performance as the dependent variables and fund age dummies as the independent variables.

The observed pattern of investment returns over a fund's life indicates window-dressing behaviour. Previous research has shown that fund managers actively manage valuations of their current portfolio. Among other things, they overstate the value of their portfolio in times of fundraising (Jenkinson et al., 2013). Beyond such valuations of unrealized portfolio companies, our results suggest similar behaviour in realizing investments. Early on in a limited partnership's life, before closing a follow-on fund, fund managers seem to divest successful investments to impress potential investors of such a new fund. To avoid hampering fundraising, mediocre or poorly performing investments are held until a follow-on limited partnership is finally closed.

To test whether the observed pattern is really related to fundraising cycles, we split the sample of deals into two contingents: whether the fund manager already raised a follow-on fund, that is this new limited partnership had a final closing, at the time of deal exit or not. Multivariate regressions confirm that a fund's relative deal performance is significantly worse after fundraising for a follow-on fund is completed. We find this drop in investment returns to be about three times greater in the case of VC partnerships.

At first glance, these findings of varying returns over a fund's life and falling returns after a new fund is raised could very well fit the limited partnership governance model and do not necessarily represent an agency problem: PE firms have a limited time of ten or more years to make money from their investments. Most capital is committed very early on in a fund's life. Very early on in a fund's life, fund managers are able to identify the best portfolio companies that are exitable, that is attractive to acquirers or the stock market. Consequently these investments 
are directly harvested in the second and third years. This behaviour should be in fund investors' interests, since it reduces the illiquidity of investments in the PE asset class. The remaining portfolio then consists of poor - so-called living dead investments (Phalippou and Gottschalg, 2009) - and mediocre investments and deals whose future development cannot be predicted.

The pattern in which very poorly performing investments are then realized to focus on the remaining 'best of the rest' investments in the portfolio could be in the interests of the LPs in this fund if it maximizes total fund returns. This would also explain the more pronounced pattern in the VC industry, which is characterized by a higher risk return profile and greater involvement of fund managers in helping the portfolio company succeed (Kaplan and Strömberg, 2009). Hence, there is a stronger incentive to focus on a few high-potential deals and writing off the rest.

Such a pattern would also provide a rational explanation for raising a new fund after three to four years. If the capital from the current fund is invested and only mediocre and poor deals are left, fund managers would not have a chance of making new investments (some of which will be good. It seems the financial intermediation is suboptimal if fund managers spend the rest of a fund's lifetime (seven or more years) just managing the portfolio of the remaining deals that are hard to predict. Accordingly, it seems sensible for them to raise a new fund and dedicate a substantial amount of time and resources to making new investments through it while making the best out of the remaining portfolio of the current fund.

However, this explanation of the patterns observed is unidirectional and implies that the decision to raise a new fund follows from having invested most of the capital from the current limited partnership. In particular, just ensuring the ability to invest does not explain increasing fund sizes over time; rather, it hints at a moral hazard issue between the GP and the LPs of the current fund. An indication of this agency problem would be a particularly pronounced drop in returns after a follow-on fund was raised in case fund size growth between the current and follow-on funds is high. In other words, PE firms should aim at signaling particularly strong returns early on in the current fund's life just to raise a much larger subsequent fund yielding substantial income from management fees. In line with a moral hazard interpretation, we find that the drop in returns is particularly strong if the follow-on fund is much larger than the current one.

Another alternative explanation could be that windows of fundraising opportunities and favourable exit markets just emerge simultaneously. The PE asset class is subject to strong cycles and is characterized by phases of strong capital inflow (Gompers and Lerner, 2000). If there is a 
large amount of capital in the market, deal returns from exits will be high and, at the same time, a follow-on fund is more likely to be raised. This would also explain the pattern we observe. We test this alternative explanation and indeed find exit market conditions to have a substantial effect on deal returns. However, we also find that investment returns drop after the final closing of a new fund in any market environment. Hence, we conclude that fund dynamics are at play beyond the simple simultaneity of favourable exits and fundraising markets.

Further multivariate tests show that the decreasing deal returns after a new fund is raised are a phenomenon that has emerged in more recent years. Recent studies show that the PE industry has matured since the end of the 1990s (Braun et al., 2013; Sensoy et al., 2013). In line with these studies, we show that the sharp decline in investment returns after a follow-on fund is raised is significant only for buyout and VC transactions realized after 1998. A likely interpretation is that raising a new fund has become substantially more difficult in a matured PE industry. Consequently, there is a stronger incentive for PE firms to signal skills through good performance and, thereby, facilitate fundraising activities. This scenario would definitely represent a moral hazard issue if PE firms left money on the table for LPs in the current fund by prematurely exiting deals to support fundraising for another limited partnership.

Actually, we would need to know what returns the deals exited before the final closing of a follow-on fund would have yielded if the PE firm kept them longer. We address this question by looking at a subsample of more than $700 \mathrm{PE}$ investments in our sample that were realized by bringing a private enterprise public. If some of these companies went public prematurely just to support fundraising activities, we should find more pronounced underpricing among deals exited prior to the final closing of a follow-on fund (Gompers, 1996). For VC partnerships, we find companies that went public to be significantly younger and to exhibit higher underpricing prior to raising a new fund. We also show that this finding applies to all VC fund managers, irrespective of their reputation in the VC market. Therefore, our finding should not be confounded with the grandstanding phenomenon described in the seminal work of Gompers (1996). However, we do not find such a pattern for IPOs from the buyout limited partnerships in our sample.

Our paper relates to three major strands of literature. First, several studies address the GP-LP relationship in PE limited partnerships (Chung et al., 2012; Kandel et al., 2011; Metrick and Yasuda, 2010; Robinson and Sensoy, 2013). They primarily question whether the current compensation structure of limited partnerships actually aligns the interests of fund managers and 
their investors. The results provided so far are inconclusive. Metrick and Yasuda (2010) doubt the alignment of interests, since only one-third of fund managers' compensation is performance based. In contrast, Chung et al. (2012) argue that the performance of the current fund ultimately affects the size and, therefore, the management fee of the follow-on fund. Hence, the present value of performance-based compensation is higher than assumed by Metrick and Yasuda (2010). However, most previous studies suffer from a lack of large-scale data and use theoretical frameworks and simulations instead. Based on our unique dataset with return information on more than 10,000 investments by more than 700 limited partnerships, we empirically disclose that the current structure of limited partnerships does not seem to ultimately align the interests of fund managers and their investors. Second, our results are in line with Braun et al. (2013) and Sensoy et al. (2013), showing that the fundamentals in the PE industry changed around the start of the new millennium. Hence, researchers and practitioners are asked to question current wisdom on PE, since some of it could already be outdated. Third, there are first studies that examine alternative forms of financial intermediation in the PE industry. For example Fang et al. (2013) test the performance of the direct investments of institutional investors in portfolio companies and find slight outperformance compared to comparable co-investments by limited partnerships. Our results encourage researchers and practitioners to look further for innovative forms of financial intermediation in PE.

The remainder of the paper is structured as follows. Section 2 carefully explains our dataset, considering fund- and deal-level data and sample selection issues. We discuss variations in deal performance over time in Section 3. Section 4 presents the results for suboptimal financial intermediation in the context of PE limited partnerships, while Section 5 considers possible alternative explanations for our findings and displays several robustness checks. Section 6 concludes the paper.

\section{Data}

Our analyses are based on a proprietary deal-level data set of about 24,000 deals from 1,385 VC and buyout funds. This information was gathered by three large FoF managers acting as LPs in VC and buyout funds. When PE firms raise new funds, they approach potential LPs and ask for their commitment to the new fund. Given that these commitments typically involve millions of US dollars, institutional investors undertake extensive due diligence efforts to come to an 
investment decision. Information in our data set stems from such due diligence carried out between 2007 and 2010. As part of such due diligence efforts, PE firms are asked to provide information on their entire track record of all historic deals and funds. It is important to note that this detailed information is collected for all funds that aim to raise a new fund and not only those in which the LPs finally decide to invest. Thus, the data set does not mirror the investment decisions made by the three LPs. The particular strength of our data set is that it contains, besides other information, the complete deal-level cash flow history at the time of LP due diligence, enabling us to compute exact deal-level performance. We are aware of only one somewhat related study, however, focusing solely on buyouts that has comparable deal- and fund-level data (Lopez-de-Silanes et al., 2013). Another strong point of our data set is that we assign each deal to the limited partnership through which the investment was made and we have comprehensive information at the fund level as well. We are not aware of any study presenting a comparably sized PE sample that covers about 40 years (the number of investment years from 1976 to 2007) which allows exact deal performance computations. However, there are inevitable sample selection issues. For example PE firms that decide not to continue PE investing - often because of the poor performance of prior funds or because management teams cease to exist - will not seek new money from LPs. Therefore, these GPs will not be part of our sample. The following section addresses our data selection issues in more detail.

\subsection{Sampling and selection issues}

For a detailed description of potential sample selection issues in our data set, we refer to Braun et al. (2013), who use the same initial database as a foundation for their analyses. Basically, there are two major sample selection issues: First, there are funds that do not seek money from FoFs. This is a selection issue if funds that do not seek investment from our three FoFs are not random and conform to a certain pattern. However, the latest due diligence, from which information stems in our sample, took place in 2012. Since LPs significantly gained power within the GP-LP relationship since the financial crises and fundraising for fund managers has become more challenging, we are confident that this kind of potential bias is not a significant issue in our sample.

Second, we simply cannot avoid a small survivorship bias in the sample. Any fund manager who chooses not to continue operations and quit the sector is not part of our data set. That said, 
we believe this bias to be rather small. Unsuccessful fund managers who aim to raise new funds but fail to receive enough money from investors to close a limited partnership are included in our sample. Our data set covers all funds sought for investments, independent of whether they received money from the FoFs or successfully closed a new fund. However, our sample does not include fund managers who have not raised new funds, e.g. in case they decided not to continue operations. These fund managers would be relevant if analysing absolute fund and deal returns to compare and benchmark PE as an asset class. However, in this paper we adopt another perspective and analyse fund relative deal performance over a fund's lifetime. This means we compare one deal with the other deals by the same fund manager within the same fund. The absolute level of performance is irrelevant in such a comparison. Thus, we strongly doubt that this bias is of any relevance in our study.

\subsection{Funds}

Starting with the three institutional investors' databases, we construct our final sample in several steps. First, we start with the entire data set of $\mathrm{VC}$ and buyout funds and ensure that we observe only entire fund portfolios, that is, we have gathered the data for all deals done through the fund at the time of the LPs' due diligence. To this end, we first remove all annex funds and pre-funds from the initial sample. Second, although the LPs asked the fund managers to provide their entire track record of previous deals, some of the information in the 1,385 fund portfolios was not complete. We delete all these incomplete fund portfolios, ending up with a second, restricted sample of 27,791 deals that represent the complete fund portfolios of 1,298 funds at the time of the LPs' due diligence.

Further, to obtain meaningful results, funds need to have a certain maturity. If fund managers raise a follow-on fund quickly after the current one (with a median of 54 months between the final closings of two successive funds in our sample), the current fund's investment and divestment activity as fund due diligence presented to potential investors often has only limited implications in terms of what it will look like at fund maturity (after ten or more years). In particular, many of these young, immature funds have already shown considerable investment activity but have not yet realized most of their investments, resulting in high shares of unrealized investments. Therefore, we first remove all immature funds with a vintage year after 2003. Then, we delete highly unrealized funds, that is, funds in which $30 \%$ of investments are still unrealized. 
We thereby ensure that the observable divestment patterns are meaningful. This due diligence procedure should lead to meaningful results and has been applied similarly by Ljungqvist and Richardson (2003). Third, since we collected data from three independent FoFs, we have funds that appear twice or three times within the data set. Therefore, we remove all funds with multiple appearances from our sample. We end up with a restricted sample of 19,291 single deals by 824 different PE funds. The $824 \mathrm{PE}$ funds consist of 564 buyout and $260 \mathrm{VC}$ funds.

Finally, to investigate topics related to fund dynamics, we identify the closing dates of the funds' follow-on funds, that is the next fund raised by the same PE firm. To this end, we first match the 824 funds with the Thomson One Banker fund database. If we do not observe the direct follow-on fund in our proprietary database or in the Thomson One Banker database, we remove the unmatched funds from our restricted sample. We were able to find follow-on fund final closing information for 702 funds, which are the basis for our final restricted sample. This sample contains 10,566 realized single investments made through these 702 PE funds.

Table 1 displays descriptive statistics for this sample. Panel A shows fund-level information in terms of fund performance and fund characteristics. The average fund size in our sample is 487.7 million USD, while the median is only 193.4 million USD. The mean buyout fund in our sample realized 14.2 investments, while the mean VC fund exited a total of 21.6 portfolio companies.

\subsection{Deals}

While we retain only highly mature funds in our sample, we go one step further and include only fully realized deals within these portfolios in our deal-level analyses. We use this sample to exhibit patterns of PE deal performance. Panel B of Table 1 displays deal-level sample descriptions in terms of deal performance, equity investment size, holding period, and exit year. Panel $\mathrm{C}$ shows distributions in terms of the country in which the portfolio company is located and its industry classification. Panel B shows that the mean equity investment (by the corresponding limited partnership) in a portfolio company is 18.4 million USD, while the median is only 4.3 million USD. The mean time between the initial investment of a VC firm and its exit (holding period) is 50.5 months, or 4.2 years, with a median equal to 41.9 months, or 3.5 years. Further,

Panel C shows the comprehensive nature of our sample in terms of geography and industry distribution, respectively. Over $50 \%$ of the portfolio companies in our sample are based in North 
America. The share of North American VC deals in our sample is even higher, at $71 \%$. This is not surprising, given the global dominance of the US VC market. The industry distribution shows that the dominant industries of $\mathrm{VC}$ investment activity are health care and technology, which comprise over $50 \%$ of the deals in our sample. While buyout deals are more evenly distributed across industries, $23 \%$ of the investments are in industrials and $15 \%$ in consumer goods. Altogether, these numbers indicate that our sample is highly representative of the PE universe.

To the best of our knowledge, there are no other comparable large-scale data sets with real cash flow data that allow the benchmarking of performance numbers. Lopez-de-Silanes et al. (2013) use a dataset of 7,452 buyout deals (5,106 of which are fully realized) and report a median IRR of $21 \%$ and a median PME of 1.3 . These values are very similar to the median IRR of $20 \%$ and the median PME of 1.29 for buyout investments in our sample. Cochrane (2005) approximates the returns of a sample of 7,765 VC-backed companies drawn from the VentureOne database from valuation changes between financing rounds and reports a mean $\log$ return of $15 \%$. The author uses maximum likelihood estimations that correct for selection bias issues. Further, Cumming (2008) reports a median IRR of $15 \%$ for 223 North American VC deals. The VC deals in our sample exhibit lower returns compared to these studies. The average IRR of our 4,734 realized deals is $10 \%$, while the median IRR is $-7 \%$. This finding is most likely a result of sampling through institutional investors' databases that include data on all funds that ever tried raising money from them. Compared to former studies on VC deal performance, we are confident that this is a more realistic portrayal of the universe of early-stage private investments. Altogether, this high general representativeness in combination with the chosen approach to the question under investigation - that is comparing fund relative investment returns - gives us much confidence that our results are generalizable to the entire PE asset class.

$$
\text { [Include Table 1] }
$$

\section{Deal returns over a fund's life}

Panel A of Table 2 presents the mean, median, and standard deviation of the deal-level PME and IRR values in buyout and VC funds, clustered by years after the first closing. For example the mean PME is 2.11 for all deals exited in the second year (from the 13th to the 24th month) after the first closing of the fund through which they were made. Panel A reveals a clear pattern of higher deal PMEs in the second and third years. The mean values of 2.11 (median 
1.24) in the second year and 2.25 (median 1.21) in the third year represent the highest performance of all years. In neither the first year (mean PME 1.45) nor the fourth and fifth years (mean PMEs of 1.69 and 1.57, respectively) does performance come even close to the values in the second and third years. To some extent, the returns recover after the fifth year and almost reach the level of deals in the second and third years. For instance, the mean PME of all deals exited in the seventh year is 1.97 . At the end of a limited partnership's life, deal returns again drop to, for example an average mean PME of 1.37 in the 12th year. It is probably noteworthy that we observe a substantial amount of the 1,367 deals that are realized more than ten years after the first closing. Half of these deals (684 transactions) are even exited by funds older than 12 years.

The IRR returns in Panel A of Table 2 paint a very similar picture. Investment returns in the second and third years are superior to those of all the other years. We think This pattern is very well explained by the nature of the IRR calculation, which benefits short holding periods. The deals realized in the second and third years must have below-average holding periods because the funds through which they were made are still very immature. The average holding period in our sample (see Table 1, Panel B) is 50.5 months, or about four years. This is considerably longer than the longest possible holding period of 36 months among deals exited in the second and third years (i.e. if a deal were made on the day of the first closing and exited at the end of the third year). This mechanism also explains the high IRRs of deals exited during the first year.

In sum, we find a structural pattern for deal returns over a fund's life for buyout and $\mathrm{VC}$ funds. The returns in the second and third years are substantially higher than the returns in any other years of the limited partnership. Further, investments exited around a year 6 yield high returns for investors. When performance variation is considered, investments in the second and third years also exhibit higher variations in returns and lower numbers of investments realized than in later periods of a limited partnership. The standard deviations of deal PMEs in the overall sample (Panel A of Table 2) in the second and third years are 2.82 and 3.15, respectively, and, again, represent the highest values of all years (except for all deals after the 12th year). Another difference is that many more deals are realized later on in a fund's life. While we observe 1,314 exits in the second and third years combined, fund managers realized 1,185 deals in the seventh 
year alone. The number of exits peaks in the relatively poorly performing fifth and sixth years, with more than 1,700 exits in the fifth year.

Panel B and C show that this pattern basically applies to buyout and VC funds alike but seems to be more pronounced for VC funds. It is particularly striking that deal-level performance is extremely low during the fourth and fifth years. The median PMEs of VC investments in the fourth and fifth years are 0.08 and 0.04 , respectively (Panel C). The median IRR is $-62 \%$ in the fourth year and $-59 \%$ in the fifth year. Apparently, most of these exits are complete write-offs. Overall, the standard deviation of performance for $\mathrm{VC}$ investments is significantly higher than for buyout investments, which reflects the higher risk associated with investments in early-stage companies.

One could argue that the pattern we observe for absolute deal performance does not result from intra-fund logic but, rather, from different realization strategies or patterns by different fund managers. For example an extremely successful or experienced fund manager could theoretically exit the entire portfolio within the first years after the first closing. Less successful or experienced fund managers could need more time to do so. Hence, we would observe such a pattern due to heterogeneity in fund manager skills, not to intra-fund dynamics.

\section{[Include Table 2]}

For this reason we compute the fund relative performance PME score for each deal in our sample. This score represents the difference (in percent) between absolute deal performance and absolute fund performance. For example a value of +0.1 for this intra-fund performance score indicates a deal PME that is $10 \%$ higher than the corresponding fund PME. A score of zero is assigned to a deal that yields exactly the same return as the fund, on average. If the pattern observed from absolute deal returns were just an artefact of heterogeneity in fund manager skill, this intra-fund deal return score would show no substantial peaks and would be quite stable over a fund's life. Figure 1 displays the mean values for this fund relative performance measure over a fund's life. There are three separate graphs: one for the entire sample of buyout and VC funds and one for each of the two fund types.

Figure 1 reveals that deal PME returns vary strongly over a fund's life. Even when the level of performance of each fund (comparable to fund fixed effects) is accounted for with our fund relative performance score, investment returns exhibit the observed structural pattern of 
varying performance over the life of limited partnerships. For the entire sample of buyout and VC funds, the mean deal returns in the second and third years are almost $40 \%$ higher than the final fund performance. Deal returns drop below zero in the fourth and fifth years. The return values rise slightly above fund returns in the sixth to eighth years. Finally, the mean relative performance scores fall to about $-10 \%$ in the 12 th year.

Figure 1 also underlines the more pronounced performance differences over time within VC limited partnerships. For example deals in the second year yield an average PME that is approximately 50\% higher than the corresponding fund's PME. Similarly, this mean deal score drops to almost $-30 \%$ in the fifth year. ${ }^{2}$

\section{[Include Figure 1]}

We also test whether this pattern of changing deal returns over a fund's life holds in a multivariate setting. Table 3 presents deal-level Tobit regressions (left censored at -1) of the fund relative PME score on fund life year dummies that indicate the year after the first closing of the limited partnership in which a deal was realized. The reference category is the third year of the fund's life. We include in these regressions the log of the equity investment size (in millions of US dollars) and the log of the holding period (in months) as controls. Further, in all regressions we control for fixed effects related to the exit year, industry, and region of the investment. Exit year fixed effects are considered for the period between 1976 and 2010. Industry fixed effects are based on ten basic Industry Classification Benchmark (ICB) categories and seven regions (see also Panel C of Table 1).

Column 1 of Table 3 displays the results from a regression on the entire sample of 10,548 transactions realized by buyout and VC limited partnerships. In this model we also use a dummy variable that equals one if the investment is carried out by a VC fund and zero if by a buyout fund. The results clearly confirm the pattern of strong return variations over a fund's life. The coefficients for all the fund years except the second are strongly negative and highly significant. For example the coefficient for the fifth year is -0.77 , which, in economic terms, means that in a multivariate setting deal PMEs in this year are $74 \%$ lower than in the third year (normalized to

\footnotetext{
${ }^{2}$ It is noteworthy that the mean intra-fund performance scores for buyout funds are hardly ever negative (except for the 12th year in a fund's lifetime). This observation reflects the skewed performance distribution in PE deals. The mean values are exceptionally high due to few highflyers.
} 
the fund PME). Further, returns in the third year are also $49 \%$ higher than in the seventh year. In turn, returns in the second year are not statistically different and even slightly higher, which confirms the patterns shown in Table 2 and Fig. 1.

We then separately estimate the identical model for the buyout fund subsample that contains 5,821 realized deals (Column 2 of Table 3) and the VC fund subsample of 4,727 realized transaction (Column 3 of Table 3). These regressions confirm that the return variation over a fund's life is indeed much more pronounced among VC funds. In the fifth year after the first closing, deal returns in buyout partnerships are about 57\% lower than in the third year. This number amounts to even $110 \%$ in VC funds. Similarly, deal returns in buyout funds are only about $40 \%$ and $43 \%$ lower in the sixth and seventh years, respectively, while the outperformance of deals in the third year is $77 \%$ and $70 \%$, respectively, in the VC funds in our sample.

While basically confirming this structural pattern, multivariate analysis shows that the superior performance in the early years of a limited partnership stands out. Hence, in further analysis we focus on explaining what drives this particular peak. The regressions also underline that buyout and VC funds exhibit a structurally similar function but it is more distinctive for VC funds. Therefore, we also run separate regressions for buyout and VC funds in further analysis.

[Include Table 3]

\section{Moral hazard in limited partnerships}

Given these variations in returns over a fund's life, the question is why do they occur? An explanation for this pattern could be the recurring fundraising cycles of fund managers. Previous studies state that fund managers raise a new fund every three years (see, e.g. Chung et al., 2012). Hence, the explanation for such a peak in the second and third years of a fund's lifetime could be a follow-on fund being raised at that time. Fund managers could want to support their fundraising activity by demonstrating their ability to realize successful investments (Gompers and Lerner, 1999). Therefore, the higher deal performance in the second and third years of the current fund would coincide with marketing activities to raise a new fund. This scenario points to a potential moral hazard issue stemming from the GP-LP relationship in the asset class, in which fund managers window-dress to signal superior quality. Therefore, they (prematurely) exit their best deals to raise the next fund and postpone the liquidation of poor deals until a follow-on fund is finally closed. In other words, we expect GP behaviour to fundamentally change when a follow- 
on fund is raised. To test whether the drop in performance after the third year coincides with fund managers' fundraising cycles, we split the sample into deals exited before the final closing of a follow-on fund by the same fund manager and those realized thereafter. Column 1 in Table 4 provides an overview of the 10,548 transactions realized by 702 PE funds, clustered by whether they were realized before or after a follow-on partnership had a final closing. ${ }^{3}$ In Column 2, 5,821 realized deals made through 452 buyout funds are split according to this logic, as are 4,727 transactions realized by $250 \mathrm{VC}$ funds in Column 3.

The mean time between the first closing of the current limited partnership and the final closing of the follow-on fund in our sample, reported in Panel A of Table 4, is 57.5 months (4.8 years), with a median value of 52.0 months (4.3 years). The frequency of raising a new fund in our sample is higher for VC fund managers, who, on average, raise a new fund after 53.5 months (4.5 years), while it takes buyout fund managers half a year longer, that is 61.4 months (5.2 years), to finally close a subsequent fund.

Panel B of Table 4 exhibits deal-level differences between the pre and post subsamples. As expected, absolute PME performance and fund relative PME performance are substantially higher before the final closing of the follow-on fund for the entire sample (Column 1). Measured in absolute PMEs, the difference is about 0.4 PME (2.07 - 1.69 in terms of mean values, or 1.23 0.84 if measured in median values). Again, this difference is greater for VC funds (Column 3), for which the drop in PME amounts to more than 0.7 in mean values, while it is only about 0.3 for buyout funds (Column 2). While a much smaller effect, the highly significant Wilcoxon ranksum test indicates that it seems to be significant for buyout funds as well. Panel B also shows that the investment sizes of deals realized before the final closing of the follow-on fund are smaller than those exited after this point in time. This applies equally to buyout and VC funds. As expected, holding periods in the pre phase are much shorter than in the post phase. The average deal duration before another fund is raised is 34 months (2.8 years) and constant across buyout and VC funds. Altogether, these deal-level numbers are in line with the interpretation that fund managers realize early on those selective (relatively small) deals that yield high returns and could

\footnotetext{
${ }^{3}$ We refer to the first closing of the current limited partnership because investment activity starts at this point in time. In turn, fundraising activities for a follow-on fund end with the final (not the first) closing of this new limited partnership. For this reason, we consider the final closing of the follow-on partnership to be the right point in time to split the sample of investments and investigate diverging fund dynamics. However, unreported robustness tests using first closing of the follow-on fund as cut-off date show that the impact is very marginal.
} 
help in marketing activities to raise a new fund. The remaining portfolio of companies is kept longer and, once realized, yields lower returns. This is in line with the interpretation that fund managers exit the good deals in their portfolio early on and keep mediocre or bad deals for the period after fundraising. Of course, the question then arises as to whether fund managers actively keep seemingly worse deals or whether this pattern is part of the business model. We address this question in more detail when examining the underpricing of PE-backed IPOs.

To provide further insight into the differences in investment returns contingent on the fundraising logic, for each limited partnership in our sample we build two synthetic portfolios of investments (Panel C in Table 4). For each limited partnership, the first synthetic fund contains all investments that were realized before the final closing of a follow-on fund. The second synthetic fund, from the same limited partnership, comprises all deals that were exited thereafter. For example suppose a limited partnership, called Fund II, was initiated in January 1996 and liquidated in December 2005. The follow-on limited partnership by the same fund manager, called Fund III, had its final closing in June 2000. The first synthetic fund of investments from Fund II contains all deals that were exited before June 2000 (pre), and the second synthetic fund contains all deals realized after this date (post).

The mean number of deals exited by buyout and VC funds during the shorter pre phase is about six, significantly lower than the 11 realizations in the post stage. This asymmetry is, again, much stronger in the case of $\mathrm{VC}$ funds. While the ratio of deals exited after the final closing of the follow-on venture fund to those exited before then is a little less than three to one (with mean values of about 15 and six in the post and pre stages, respectively), the same ratio is only two to one for buyout funds (with mean values of nine exits after compared to five exits before closing a follow-on fund). Interestingly, Panel $\mathrm{C}$ also reveals that the absolute number of home runs, that is exceptionally successful deals yielding a PME larger than three, is slightly higher in the post phase. The mean numbers of home runs before and after the final closing of the follow-on fund in the entire sample are 1.16 and 1.79 , respectively. Relative to the absolute number of exits, on average 1.16 out of 5.70 deals are home runs in the pre phase (20\%) and only 1.79 out of 11.09 $(16 \%)$ are home runs in the post phase. The numbers also show that the relative share of underperforming deals, with a PME below one, realized in the post phase (54\%) is higher than in the pre phase (44\%). Again, this applies particularly to VC funds. These numbers are in line with the average PME numbers reported in Panel B of Table 4. 
Similarly, given that deal-level numbers show investments to be structurally smaller in the pre phase, it is also intuitive that the distribution share is even smaller for both types of funds. In the last row of Panel $\mathrm{C}$ of Table 4, the distribution share is the relative amount of proceeds to fund investors in each of the two stages, divided by the final amount of proceeds (at fund maturity). For example if a fund distributed 100 million USD to its investors (gross of carried interest and fees) over its entire life, a distribution share of 0.5 for both stages indicates that 50 million USD were gained through investments realized at each stage.

Based on median numbers, only $25 \%$ of total returns in buyout funds are distributed before the final closing of the follow-on fund and $75 \%$ thereafter. This discrepancy is even higher for VC funds, which only return $15 \%$ of total proceeds to investors during the first years and $85 \%$ after a new fund is raised.

Altogether, Table 4 suggests that returns and investment characteristics strongly differ between when the current fund is at the centre of the fund manager's attention and when another partnership has already been raised. We test in a multivariate setting whether deal returns are lower when a new fund is raised by running several Tobit regressions (see Table 5).

\section{[Include Table 4]}

The regression setup in Columns 1 to 3 in Table 5 is identical to that described in Table 3 in terms of estimation method, the dependent variable, and controls. The only difference is that we replace exit year dummies with a binary variable indicating whether the transaction at hand was realized before the final closing of the follow-on fund or after. The coefficient of this dummy variable is negative and significant in Column 1, a regression on 10,548 investments realized by buyout and VC partnerships. In economic terms, the average deal in the post phase yields an approximately 34\% lower PME. The negative and significant coefficient of the same dummy in Column 2, a regression on 5,821 realized deals by buyout funds, indicates that the effect is only about $-16 \%$ in buyout funds. In turn, the effect is $-56 \%$ when running the identical regression on almost 5,000 deals exited by VC funds in Column 3. Once again, these results confirm that performance drops after a new fund is raised for both buyout and VC funds, but the drop is much greater for the latter.

The results could indicate a moral hazard issue between the GP and the LPs of the current fund: If so, the drop in intra-fund performance should be more pronounced when the follow-on 
fund is significant larger than the current fund. Prior research already shows that strong performance of the current fund leads to larger sizes of future funds (e.g. Gompers, 1996; Kaplan and Schoar, 2005). Larger future funds are of particular interest since they convert into larger fees and, hence, higher total compensation (Metrick and Yasuda, 2010). Assuming a moral hazard issue exists, the difference in deal performance between before and after the final closing of a follow-on fund should be even greater for those funds that led to significant growth in the size of the follow-on fund. To test the impact of follow-on fund growth rates, we interact follow-on fund size growth with the post final closing dummy. ${ }^{4}$ The dummy variable takes on the value of one if fund size growth is above the median of our sample (79\% growth) and zero otherwise. The results confirm the moral hazard hypothesis. Column 4 of Table 5 reports the results of regressing the relative PME performance of 1,024 synthetic funds - before and after the final closing of follow-on funds, as described above - from 512 limited partnerships on post final closing, fund size growth, and the interaction of the two. We analyse the impact of fund size growth at the synthetic fund level because, by definition, there is no variance in this variable at the investment level before and after the final closing of a follow-on fund.

The coefficient of the interaction of post final closing and fund size growth is negative and strongly significant. The joint effect of these three variables for buyout and VC funds in column 4 of Table 5 is highly significant (F-value 18.4). In economic terms, the (mean) marginal performance delta of two synthetic funds - one including all deals exited before the final closing of a follow-on fund and the other all deals exited after - is $34 \%(23 \%-(-11 \%)=34 \%) 5$ of the final fund performance for funds with strong fund size growth. In contrast, we find a marginal effect of only $13 \%(6 \%-(-7 \%)=13 \%)$ for funds with low fund size growth. Columns 5 and 6 show the separate results for buyout and VC funds. Again, the drop in returns is significantly higher in the case of VC partnerships. While VC funds with high fund size growth display a marginal performance delta of $57 \%$, buyout fund performance differences between synthetic funds before and after the final closing of a follow-on fund are, on average, only $22 \%$.

\footnotetext{
${ }^{4} \mathrm{We}$ are aware of a potential endogeneity issue, since higher fund returns prior to final closing are associated with larger follow-on funds (Gompers, 1996). To address this issue, we use a relative variable measuring the performance of synthetic pre and post final closing funds in relation to final fund performance. Hence, we do not focus on absolute performance but, rather, measure the intra-fund drop in performance from before to after the final closing of a follow-on fund. We are confident that potential endogeneity is thereby minimized.

5 Throughout this paper, we report average marginal effects obtained by using Stata's (post-estimation) margin command.
} 


\section{[Include Table 5]}

\section{Robustness Test}

While our results in Table 5 indicate a moral hazard issue and window-dressing behaviour in PE funds, there are possible alternative explanations for the observed pattern. Is it really a moral hazard issue or are we observing a pattern that is due to a different cause? There are several interpretations of the observed empirical pattern. First, it could simply be that windows of fundraising opportunities coincide with favourable exit market conditions. Second, the pattern could be inherent to the business model, since the mostly 10-year life of limited partnerships is long enough to keep mediocre deals that cannot be realized quickly without significant losses. Consequently, the actual deals of interest, good deals, are realized early on and it is in the LP's interest to raise a new fund so that new good deals can be made and, at the same time, money preserved. Third, the pattern could also be desirable for LPs in the current fund because it mitigates the illiquidity problem, since returns are distributed continuously and early on.

\subsection{Fundraising cycles}

One alternative explanation for the drop in returns after a new fund is raised could be the simultaneity of favourable fundraising and exit markets. If average returns are high, there are substantial fund inflows into the asset class (Gompers and Lerner, 2000). In such times, the probability of raising a new fund is much higher. Thus, the higher deal returns observed before fundraising could be the result of hot exit markets and not fund dynamics. To address whether the difference in relative returns is mainly driven by market cycles, we interact the post final closing dummy with a binary variable indicating hot exit markets.

To assess this alternative explanation, we build an interaction model in Columns 1 to 3 of Table 6. Therefore, we use the same model as in Panel A of Table 5 and add a binary market environment variable (hot exit market) and an interaction term between this dummy and the binary post final closing dummy. To build this market environment number, we first count the number of global IPOs per exit year and split these years into two categories of equal size: Those years with low numbers of IPOs are given a value of zero for our binary market environment variable and indicate cold exit markets, while those years with high numbers of IPOs are given a 
value of one and indicate hot exit markets. In a second step, we assign this variable to each realized transaction in our sample, based on exit year.

The joint effect of these three variables for buyout and VC funds in Column 1 of Table 5 is highly significant (F-value 66.2). The marginal effect of the post final closing dummy on the fund relative PME performance is $-43 \%$ during times of unfavourable or cold exit markets (with an estimated average fund relative PME of $-4 \%$ before the final closing and $-47 \%$ afterwards) and $-36 \%$ during hot exit markets (with a fund relative PME of $+23 \%$ before the final closing and $-13 \%$ afterwards). These numbers show that, as expected, deal returns are generally higher when exit markets are hot and that the sharp decline in investment performance is almost equally sharp in both exit market environments.

In Column 2 of Table 5 we repeat this analysis for the buyout fund subsample. Again, the two variables of interest and the interaction term are jointly significant (F-value 8.3). The estimated average fund relative PME during cold exit market phases is $+7 \%$ before the final closing and $-11 \%$ in the post stage, representing a drop in relative performance of $-18 \%$. These numbers amount to +17 in the pre phase and $-2 \%$ in the post phase and thus a drop of $19 \%$ when exit markets are hot. For VC funds (Column 3) we find a highly significant joint effect (F-value 71.9). When exit markets are unfavourable, the average deal PME before the final closing of a follow-on fund is $-22 \%$ (relative to fund PME) and $-96 \%$ when a new fund has already been raised. This represents a drop of 74\%. In times of hot exit markets, the fund relative deal PME is $+32 \%$ in the pre phase and $-29 \%$ in the post phase, a decline of $61 \%$.

The results from Columns 1 to 3 of Table 5 show that the basic pattern of changing deal returns contingent on a new fund being raised holds, irrespective of the prevailing exit market environment. In line with prior results, the gap in investment returns during hot exit markets before and after the final closing of a new partnership is smaller for buyout funds than for VC funds. Apparently, buyout firms conduct fewer deals and try to avoid underperforming deals before closing a follow-on fund. In favourable exit markets, they can realize good prices for their mediocre deals in the post phase as well, narrowing the gap between before and after the final closing. For VC firms, the interaction effect of post final closing and hot markets is stronger from an econometric as well as an economic perspective. Some VC deals do not perform at all and will be total write-offs, even when exit markets are favourable, while home runs yield extraordinary 
returns in such an environment. Overall, exit markets do not substantially moderate the effect of having raised a follow-on fund on fund relative deal returns.

\subsection{Industry maturity}

Recently, several studies have shown that the PE asset class has matured (e.g. Braun et al., 2013; Sensoy et al., 2013). In such an environment of low return levels and low performance persistence, fundraising is much more difficult. When even good fund managers are having problems maintaining good and stable deal returns in more recent years, there should be an increased incentive to present good deals to support fundraising. To test this hypothesis, we split the sample into transactions realized before and after 1999, respectively. We choose this cut-off point to provide some degree of comparability with other studies.

Column 4 in Table 6 exhibits the results for our basic regression (see also Column 1 in Table 5) on the full sample of 10,548 deals conducted by buyout and VC funds. To test the impact of the mature market effect, we interact a mature market dummy with the post final closing dummy. The mature market dummy variable takes on the value of one if the deal is exited after 1999 and zero if before. The joint effect of the three variables for the total sample, exhibited in Column 4, is highly significant (F-value 55.9). The results indicate that the overall effect of deal performance differences between the pre and post phases of a follow-on fund is largely driven by deals exited since 1999. Column 5 reports the results of the identical regression on the subsample of 5,821 deals exited by buyout funds. The coefficient of the binary variable for post final closing is negative but not significant. Overall, the joint effect of the interacting variables is significant (F-value 9.1). The estimated average fund relative PME before 1999 is $+5 \%$ before the final closing and $-8 \%$ in the post stage, a drop in relative performance of $-13 \%$. These numbers amount to +22 in the pre phase and $-37 \%$ in the post phase, or a drop of $59 \%$ since 1999.

Apparently, the observed pattern is primarily driven by more recent years in the sample. However, Column 5 in Table 6 shows that this does not apply to buyout funds. While the joint effect of the interacting variables is again significant (F-value 9.1), the effect is substantially weaker in economic terms. The estimated average fund relative PME before 1999 is $+11 \%$ before

the final closing and $+3 \%$ in the post stage, a drop in relative performance of only $-8 \%$. Since 1999, the effect has been significantly larger, with an average fund relative PME amounting to 
+15 in the pre stage and $-10 \%$ in the post stage, a drop of $25 \%$ (Column 5). We find a much more pronounced impact of the maturing PE industry on the relationship of interest for VC partnerships. The joint effect of the interacting variables is again significant (F-value 53.7). In the early years, before 1999, the average fund relative PME is $-5 \%$ before the final closing and $-27 \%$ in the post stage, representing a drop in relative performance of $-22 \%$. In recent times, since 1999, the effect has become significantly larger, with the estimated average fund relative PME amounting to $+34 \%$ before the final closing and to $-73 \%$ after the final closing, a remarkable drop in relative performance of $-107 \%$ (estimated from the regression reported in Column 6). Overall, the phenomenon of dropping deal returns after a new buyout fund is raised has only emerged in more recent years, since 1998. In contrast, the effect was negative and (weakly) significant for VC funds and deals realized before 1999. However, the effect became nearly five times larger after 1998 (Column 6) and much more statistically significant. These results hint at emerging agency conflicts between GPs and LPs in a maturing PE industry and provide further evidence that we are looking at a different beast nowadays (Sensoy et al., 2013).

\subsection{Underpricing before and after the final closing of a follow-on fund}

A major objection of all previous analyses could be that we actually need to know what the returns for deals exited before the final closing of the follow-on fund could have been had PE firms kept them longer in their portfolios. Only if these hypothetical returns are higher can we conclude that PE firms as GPs really leave money on the table. Only then will the limited partnership model not fit the business model and represent a suboptimal form of financial intermediation.

To test this, we rely on an established method and look at underpricing in IPOs to test differences in deal quality (e.g. Gompers, 1996). Column 1 in Table 7 provides an overview of 760 IPOs that we were able to identify in our sample of 10,566 realized investments by buyout and VC funds. The first interesting finding is that the number of IPOs is almost evenly split between the pre stage (369 IPOs) and the post stage (391 IPOs). This result is somewhat surprising, given that the pre stage is substantially shorter than the post stage (see Table 4).

Descriptive statistics show that underpricing is significantly higher when the company goes public before the final closing of a follow-on fund. The median difference between the closing day bid price and the initial offer price over the first day of trading is $16.3 \%$ (mean value 
$40.3 \%$ ) if the IPO was undertaken before a new fund was raised and only $9.4 \%(21.7 \%)$ if undertaken afterwards. A nonparametric rank-sum test confirms the statistical significance of this difference in underpricing. The numbers for 257 buyout firm-sponsored IPOs show that, while exhibiting the same basic pattern, the drop is not statistically significant. The drop in median value from $11.7 \%$ to $8.1 \%$ (mean values $19.7 \%$ and $18.8 \%$ ) is much smaller and not statistically significant. The difference in the overall sample is driven by the IPOs of VC-backed companies (Column 3). Looking at the median values, we find underpricing drops from $18.8 \%$ during the first years of a fund's life to $10.0 \%$ when a follow-on fund has been raised. This difference is statistically significant (based on a nonparametric test) and even larger (from $49.2 \%$ to $23.4 \%$ ) if the mean values are considered.

Table 7 also shows that companies going public are significantly younger and held for shorter periods in the portfolio when the fund is in the pre phase. Similarly, investments exhibit smaller IPO sizes when going public before a new fund is raised. This holds for both buyout and VC partnerships. Altogether, these patterns raise the question of whether these companies were prematurely sold to the public equity markets.

We conduct a multivariate analysis to test whether underpricing is more pronounced in the pre phase, controlling for the age of the company and other relevant aspects. This approach is similar to that of Gompers (1996) in his seminal work on grandstanding in PE. The results of the regressions in Table 8 confirm that underpricing is higher when an IPO is exited before a new fund is raised in the overall sample (Column 1). This effect is robust to controlling for company age at IPO, IPO size, and market effects. However, further regressions show that the effect is driven by VC funds only (Column 3). For buyout funds, exhibited in Column 2, the difference in underpricing before and after the final closing of a follow-on fund is much smaller and statistically insignificant. Following the grandstanding hypothesis (Gompers, 1996), we also test whether the effect is largely driven by less reputable fund managers. Following Krishnan et al. (2011), we employ the three-year IPO market share of PE firms as a proxy for reputation. The joint effect of the post final closing, the reputation variable, and their interaction term in the total sample (Column 4) is slightly significant at the $10 \%$ level (F-value 0.06). Surprisingly, we find no differences in underpricing for low-reputation PE firms, with 33.8\% of IPOs during the pre stage versus $33.6 \%$ during the post stage. In turn, underpricing drops from $34.5 \%$ to $27.1 \%$ for highly reputable PE firms. Differentiating between buyout and VC funds, we find no significant 
joint effect for buyout funds reported in Column 5 (F-value 1.01). Again, in Column 6 we find a jointly significant effect of post final closing, the reputation variable, and their interaction term at the $10 \%$ level (F-value 2.55) for VC funds. However, IPOs by VC firms with both low and high reputations experience stronger underpricing before a new fund is raised. If an IPO is backed by a low-reputation fund manager, the estimated underpricing is $42.4 \%$ before the final closing of a new fund and 35.2\% thereafter. For high-reputation VC fund managers, underpricing drops from $42.6 \%$ in the pre phase to $30.4 \%$ in the post phase. Hence, one could argue that grandstanding is no longer a phenomenon associated with only less reputable fund managers (Gompers, 1996). Instead, in a mature PE asset class, all PE firms are at risk of undertaking grandstanding activities, although this is only likely to be a major issue in the context of VC partnerships.

But more importantly, the findings on underpricing presented in combination with the previous results give us confidence in saying that VC firms leave money on the table by prematurely exiting deals to fuel fundraising activities. It seems that the closed-end limited partnership in its current form is no longer a suitable form of financial intermediation.

\section{Conclusion}

This paper studies the deal returns for more than 10,000 investments made by nearly 700 PE funds. We are the first to test the implications of the limited partnership governance model on actual deal-level performance. Considering intra-fund performance variations in limited partnerships, we find that deals exited before the final closing of a follow-on fund significantly outperform deals exited afterwards. This pattern strongly indicates a moral hazard issue in the GP-LP relationship that incentivizes fund managers to actively game their portfolio. The results are robust even after controlling for market cycles and deal maturity in an IPO setting. We find intra-fund performance differences between before and after the closing of a follow-on fund to be particularly pronounced in recent years, since 1999. Further, while intra-fund performance variations in buyout funds do not generally seem to be critical, these variations in VC funds are alarming. Our findings raise the question of whether the current governance structure of limited partnerships still fits the PE asset class, especially when looking at VC funds.

How do we interpret this finding? Our paper relates to other studies in the field that show a conflict between GPs and LPs in limited partnerships (e.g. Axelson et al., 2009; Chung et al., 2012; Mulcahy et al., 2012). According to Chung et al. (2012), fund managers maximize their 
lifetime income generated by current and future funds. Fund managers thus need to balance shortterm interests (the fundraising of a follow-on fund) and long-term reputation. However, the function of such a tradeoff is complex and probably not always in alignment with LP interests. Particularly for VC funds, which exhibit a higher degree of information asymmetry, our results emphasize the need to rethink current governance structures. The results indicate that LPs should consider rebalancing the weighting of fixed to variable compensation components or implementing other governance mechanisms to fully align LP interests with those of GPs. Recent developments in fundraising activities and the pressure on returns in the PE industry have given both GPs and LPs reasons to try new things. The first modifications in the PE business model are (1) direct investments of LPs in portfolio companies, (2) separate LP accounts that are committed for longer time frames, and (3) LPs becoming the shareholders of fund managers.

Further, our findings are in line with those of Braun et al. (2013) and Sensoy et al. (2013), showing that the fundamentals in this industry changed around the start of the new millennium. Overall, our results contribute to the examination of whether the current governance structure of PE funds, as a form of financial intermediation, is still adequate. 


\section{References}

Axelson, U., Stromberg, P., Weisbach, M.S., 2009. Why are buyouts levered? The financial structure of private equity funds. Journal of Finance 64, 1549-1582.

Braun, R., Jenkinson, T., Stoff, I., 2013. How persistent is private equity performance? Evidence from deal-level data. Working paper, Friedrich-Alexander University ErlangenNuremberg.

Brown, G.W., Gredil, O.R., Kaplan, S.N., 2013. Do private equity funds game returns? Working paper, University of North Carolina.

Carter, R., Manaster, S., 1990. Initial public offerings and underwriter reputation. Journal of Finance 45, 1045-1067.

Chung, J.-W., Sensoy, B.A., Stern, L., Weisbach, M.S., 2012. Pay for performance from future fund flows: The case of private equity. Review of Financial Studies 25, 3259-3304.

Cochrane, J., 2005. The risk and return of venture capital. Journal of Financial Economics 75, 352.

Cumming, D.J., 2008. Contracts and exits in venture capital finance. Review of Financial Studies 21, 1947-1982.

Fang, L.H., Ivashina, V., Lerner, J., 2013. The disintermediation of financial markets: Direct investing in private equity. Working paper, INSEAD, Fontainebleau.

Gompers, P.A., 1996. Grandstanding in the venture capital industry. Journal of Financial Economics 42, 133-156.

Gompers, P.A., Lerner, J., 1999. What drives venture capital fundraising? Working paper, National Bureau of Economic Research.

Gompers, P.A., Lerner, J., 2000. Money chasing deals? The impact of fund inflows on private equity valuation. Journal of Financial Economics 55, 281-325.

Harris, R.S., Jenkinson, T., Kaplan, S.N., Stucke, R., 2013. Has persistence persisted in private equity? Evidence from buyout and venture capital funds. Working paper no. 2304808, Darden Business School.

Jenkinson, T., Sousa, M., Stucke, R., 2013. How fair are the valuations of private equity funds? Working paper, University of Oxford.

Kandel, E., Leshchinskii, D., Yuklea, H., 2011. VC Funds: Aging brings myopia. Journal of Financial and Quantitative Analysis 46, 431-457. 
Kaplan, S.N., Lerner, J., 2009. It ain't broke: The past, present, and future of venture capital. Journal of Applied Corporate Finance 22, 1-12.

Kaplan, S.N., Schoar, A., 2005. Private equity performance: Returns, persistence, and capital flows. Journal of Finance 60, 1791-1823.

Kaplan, S.N., Strömberg, P., 2009. Leveraged buyouts and private equity. Journal of Economic Perspectives 23, 121-146.

Krishnan, C.N.V., Ivanov, V.I., Masulis, R.W., Singh, A.K., 2011. Venture capital reputation, post-IPO performance, and corporate governance. Journal of Financial and Quantitative Analysis 46, 1295-1333.

Lakonishok, J., Shleifer, A., Thaler, R., Vishny, R., 1991. Window dressing by pension funds. American Economic Review 81, 227-231.

Lerner, J., 2012. The Architecture of Innovation: The Economics of Creative Organizations. Harvard Business Publishing, Boston.

Ljungqvist, A., Richardson, M., 2003. The cash flow, return and risk characteristics of private equity. Working paper, National Bureau of Economic Research.

Lopez-de-Silanes, F., Phalippou, L., Gottschalg, O., 2013. Giants at the gate: Investment Returns and Diseconomies of Scale in Private Equity. Journal of Financial and Quantitative Analysis, (forthcoming).

Metrick, A., Yasuda, A., 2010. The economics of private equity funds. Review of Financial Studies 23, 2303-2341.

Morey, M.R., O’Neal, E.S., 2006. Window dressing in bond mutual funds. Journal of Financial Research 29, 325-347.

Mulcahy, D., Weeks, B., Bradley, H.S., 2012. We have met the enemy... and he is us. Kauffman Foundation Research Studies, Kansas City.

Musto, D.K., 1997. Portfolio disclosures and year-end price shifts. Journal of Finance 52, 15361588 .

Phalippou, L., Gottschalg, O., 2009. The performance of private equity funds. Review of Financial Studies 22, 1747-1776.

Robinson, D.T., Sensoy, B.A., 2013. Do private equity fund managers earn their fees? Compensation, ownership, and cash flow performance. Review of Financial Studies, forthcoming. 
Sensoy, B.A., Wang, Y., Weisbach, M.S., 2013. Limited partner performance and the maturing of the private equity industry. Working paper, National Bureau of Economic Research. 


\section{Table 1: Deal- and fund-level sample characteristics}

This table reports fund- and deal-level characteristics for our entire sample of 10,566 realized transactions from 702 mature buyout and VC funds (Column 1). Column 2 provides information on 452 buyout funds through which 5,832 deals were realized. Correspondingly, Column 3 exhibits statistics on $250 \mathrm{VC}$ funds that exited 4,734 transactions. We provide the mean, median, and standard deviations of performance and further characteristics at the fund level (Panel A) and deal level (Panel B). To obtain fund-level performance, we aggregate deal-level monthly cash flows gross of fees and compute equity gross PMEs and IRR as alternative measures. Further, Panel A shows fund sizes in millions of US dollars, the number of realized investments in each fund portfolio, and fund vintage years. Panel B exhibits information on deal equity gross PME and IRR, as well as equity investment sizes in millions of US dollars, holding periods in months, and the years in which deals were realized. Panel $\mathrm{C}$ shows the distribution of realized transactions in our sample across industries (ICB classification) and regions.

\begin{tabular}{|c|c|c|c|c|c|c|c|c|c|}
\hline & \multicolumn{3}{|c|}{ 1. All } & \multicolumn{3}{|c|}{ 2. Buyout } & \multicolumn{3}{|c|}{ 3. $\mathrm{VC}$} \\
\hline & Mean & Median & SD & Mean & Median & SD & Mean & Median & SD \\
\hline \multicolumn{10}{|l|}{ Panel A: Fund characteristics } \\
\hline \multicolumn{10}{|l|}{ Gross Performance } \\
\hline PME & 2.25 & 1.74 & 2.25 & 2.24 & 1.85 & 1.80 & 2.27 & 1.58 & 2.89 \\
\hline IRR & 0.38 & 0.29 & 0.40 & 0.38 & 0.31 & 0.31 & 0.38 & 0.23 & 0.52 \\
\hline \multicolumn{10}{|l|}{ Characteristics } \\
\hline Size & 494.1 & 199.5 & 811.8 & 609.3 & 247.8 & 913.7 & 285.9 & 131.3 & 525.1 \\
\hline Portfolio size (fully realized) & 16.8 & 11.0 & 18.2 & 14.2 & 10.0 & 16.3 & 21.6 & 14.5 & 20.7 \\
\hline Vintage year & 1996 & 1997 & 5 & 1995 & 1997 & 5 & 1996 & 1998 & 5 \\
\hline $\mathrm{N}$ & 702 & & & 452 & & & 250 & & \\
\hline \multicolumn{10}{|l|}{ Panel B: Deal characteristics } \\
\hline \multicolumn{10}{|l|}{ Gross Performance } \\
\hline PME & 1.81 & 0.96 & 2.73 & 1.94 & 1.29 & 2.50 & 1.65 & 0.47 & 2.98 \\
\hline IRR & 0.21 & 0.11 & 1.23 & 0.30 & 0.20 & 1.10 & 0.10 & -0.07 & 1.37 \\
\hline \multicolumn{10}{|l|}{ Characteristics } \\
\hline Size & 18.4 & 4.3 & 79.1 & 26.3 & 7.2 & 101.1 & 8.4 & 2.7 & 32.9 \\
\hline Holding Period & 50.5 & 41.9 & 33.5 & 50.6 & 42.9 & 33.5 & 50.3 & 40.0 & 33.5 \\
\hline Exit year & 2000 & 2000 & 5 & 2000 & 2000 & 5 & 1999 & 2000 & 5 \\
\hline $\mathrm{N}$ & 10,566 & & & 5,832 & & & 4,734 & & \\
\hline \multicolumn{10}{|c|}{ Panel C: Deal level industry \& regional distribution } \\
\hline & Obs. & Share & & Obs. & Share & & Obs. & Share & \\
\hline \multicolumn{10}{|l|}{ Industry } \\
\hline Oil \& Gas & 47 & $0 \%$ & & 26 & $0 \%$ & & 21 & $0 \%$ & \\
\hline Basic Materials & 201 & $2 \%$ & & 164 & $3 \%$ & & 35 & $1 \%$ & \\
\hline Industrials & 1,790 & $17 \%$ & & 1,324 & $23 \%$ & & 459 & $10 \%$ & \\
\hline Consumer Goods & 990 & $9 \%$ & & 880 & $15 \%$ & & 102 & $2 \%$ & \\
\hline Health Care & 1,690 & $16 \%$ & & 510 & $9 \%$ & & 1,190 & $25 \%$ & \\
\hline Consumer Services & 996 & $9 \%$ & & 715 & $12 \%$ & & 277 & $6 \%$ & \\
\hline Telecommunications & 958 & $9 \%$ & & 437 & $7 \%$ & & 524 & $11 \%$ & \\
\hline Utilities & 131 & $1 \%$ & & 83 & $1 \%$ & & 49 & $1 \%$ & \\
\hline Financials & 350 & $3 \%$ & & 233 & $4 \%$ & & 117 & $2 \%$ & \\
\hline Technology & 2,534 & $24 \%$ & & 810 & $14 \%$ & & 1,737 & $37 \%$ & \\
\hline Unknown & 878 & $8 \%$ & & 651 & $11 \%$ & & 223 & $5 \%$ & \\
\hline \multicolumn{10}{|l|}{ Region } \\
\hline North America & 5,931 & $56 \%$ & & 2,455 & $42 \%$ & & 3,495 & $74 \%$ & \\
\hline United Kingdom & 1,048 & $10 \%$ & & 770 & $13 \%$ & & 273 & $6 \%$ & \\
\hline Continental Europe \& Scandinavia & 1,961 & $19 \%$ & & 1,366 & $23 \%$ & & 589 & $12 \%$ & \\
\hline Asia & 296 & $3 \%$ & & 125 & $2 \%$ & & 172 & $4 \%$ & \\
\hline Oceania & 23 & $0 \%$ & & 20 & $0 \%$ & & 3 & $0 \%$ & \\
\hline Latin America & 64 & $1 \%$ & & 46 & $1 \%$ & & 18 & $0 \%$ & \\
\hline Africa & 3 & $0 \%$ & & 3 & $0 \%$ & & 0 & $0 \%$ & \\
\hline Unknown & 1,240 & $12 \%$ & & 1,047 & $18 \%$ & & 184 & $4 \%$ & \\
\hline $\mathrm{N}$ & 10,566 & & & 5,832 & & & 4,734 & & \\
\hline
\end{tabular}




\section{Table 2: Deal-level performance over a fund's life}

This table illustrates deal performance over a fund's life in our sample of 10,566 transactions realized by mature buyout and VC funds. We group transactions based on the amount of time (in years) that has passed between deal realization and the corresponding fund's first investment. Since we observe deal-level monthly cash flows gross of fees and carry, we can report equity gross PMEs and IRR as alternative performance measures. For each performance measure, we present the mean, median, and standard deviation within the corresponding year since the first closing. Panel A presents the performance results for the total sample of deals carried out by buyout and VC funds. For example deals that were exited within one year after the first closing yield a median PME of 0.75, those in the second year a median PME of 1.24, and so on. Panel B presents the performance results for the sample of 5,832 deals realized through buyout funds. Equivalently, Panel C shows the performance results for 4,734 deals realized with VC funds.

\begin{tabular}{|c|c|c|c|c|c|c|c|c|c|c|c|c|c|c|}
\hline Fund Age & All & 1 & 2 & 3 & 4 & 5 & 6 & 7 & 8 & 9 & 10 & 11 & 12 & $>12$ \\
\hline \multicolumn{15}{|l|}{ PME } \\
\hline Mean & 1.81 & 1.45 & 2.11 & 2.25 & 1.69 & 1.57 & 1.91 & 1.97 & 1.88 & 1.82 & 1.71 & 1.64 & 1.37 & 1.77 \\
\hline Median & 0.96 & 0.75 & 1.24 & 1.21 & 0.75 & 0.64 & 1.09 & 1.20 & 1.08 & 1.04 & 1.03 & 0.91 & 0.89 & 0.61 \\
\hline SD & 2.73 & 2.59 & 2.82 & 3.15 & 2.70 & 2.56 & 2.78 & 2.80 & 2.54 & 2.56 & 2.42 & 2.49 & 1.91 & 3.34 \\
\hline \multicolumn{15}{|l|}{ IRR } \\
\hline Mean & 0.21 & 0.867 & 1.103 & 0.723 & 0.131 & 0.020 & 0.134 & 0.176 & 0.149 & 0.113 & 0.112 & 0.095 & 0.174 & 0.151 \\
\hline Median & 0.11 & 0.109 & 0.329 & 0.261 & 0.000 & 0.000 & 0.141 & 0.152 & 0.130 & 0.137 & 0.123 & 0.105 & 0.091 & 0.035 \\
\hline SD & 1.23 & 2.268 & 2.213 & 1.775 & 1.326 & 1.164 & 1.016 & 0.917 & 0.836 & 0.619 & 0.482 & 0.582 & 0.915 & 1.140 \\
\hline $\mathrm{N}$ & 10,566 & 148 & 445 & 869 & 1,559 & 1,722 & 1,511 & 1,185 & 916 & 662 & 467 & 306 & 215 & 561 \\
\hline
\end{tabular}

Panel B: Buyout only

\begin{tabular}{|c|c|c|c|c|c|c|c|c|c|c|c|c|c|c|}
\hline Fund Age & All & 1 & 2 & 3 & 4 & 5 & 6 & 7 & 8 & 9 & 10 & 11 & 12 & $>12$ \\
\hline \multicolumn{15}{|l|}{ PME } \\
\hline Mean & 1.94 & 1.06 & 1.89 & 2.42 & 1.90 & 1.87 & 2.15 & 2.11 & 1.86 & 1.91 & 1.69 & 1.67 & 1.42 & 1.73 \\
\hline Median & 1.29 & 0.68 & 1.28 & 1.68 & 1.43 & 1.32 & 1.42 & 1.55 & 1.24 & 1.20 & 1.10 & 1.04 & 1.10 & 0.87 \\
\hline SD & 2.50 & 1.20 & 2.46 & 2.83 & 2.31 & 2.47 & 2.81 & 2.63 & 2.21 & 2.53 & 2.13 & 2.31 & 1.63 & 2.79 \\
\hline \multicolumn{15}{|l|}{ IRR } \\
\hline Mean & 0.30 & 1.11 & 1.02 & 0.86 & 0.33 & 0.22 & 0.25 & 0.27 & 0.19 & 0.14 & 0.12 & 0.14 & 0.14 & 0.11 \\
\hline Median & 0.20 & 0.26 & 0.43 & 0.48 & 0.33 & 0.23 & 0.24 & 0.23 & 0.16 & 0.16 & 0.13 & 0.13 & 0.09 & 0.09 \\
\hline SD & 1.10 & 2.32 & 1.99 & 1.59 & 1.14 & 1.09 & 0.97 & 0.93 & 0.85 & 0.63 & 0.43 & 0.65 & 0.73 & 0.79 \\
\hline $\mathrm{N}$ & 5,832 & 72 & 220 & 388 & 746 & 906 & 885 & 701 & 571 & 425 & 319 & 192 & 127 & 280 \\
\hline
\end{tabular}

Panel C: Venture capital only

\begin{tabular}{|c|c|c|c|c|c|c|c|c|c|c|c|c|c|c|}
\hline Fund Age & All & 1 & 2 & 3 & 4 & 5 & 6 & 7 & 8 & 9 & 10 & 11 & 12 & $>12$ \\
\hline \multicolumn{15}{|l|}{ PME } \\
\hline Mean & 1.65 & 1.82 & 2.31 & 2.11 & 1.50 & 1.22 & 1.58 & 1.77 & 1.92 & 1.67 & 1.76 & 1.58 & 1.29 & 1.80 \\
\hline Median & 0.47 & 0.94 & 1.20 & 0.91 & 0.08 & 0.04 & 0.56 & 0.65 & 0.80 & 0.77 & 0.80 & 0.69 & 0.70 & 0.30 \\
\hline SD & 2.98 & 3.39 & 3.13 & 3.39 & 3.00 & 2.62 & 2.71 & 3.02 & 3.00 & 2.62 & 2.95 & 2.77 & 2.26 & 3.81 \\
\hline \multicolumn{15}{|l|}{ IRR } \\
\hline Mean & 0.10 & 0.63 & 1.18 & 0.61 & -0.05 & -0.20 & -0.02 & 0.04 & 0.08 & 0.06 & 0.10 & 0.01 & 0.22 & 0.20 \\
\hline Median & -0.07 & 0.00 & 0.27 & 0.00 & -0.62 & -0.59 & -0.06 & 0.01 & 0.05 & 0.08 & 0.10 & 0.04 & 0.08 & -0.03 \\
\hline SD & 1.37 & 2.21 & 2.41 & 1.90 & 1.46 & 1.20 & 1.05 & 0.89 & 0.80 & 0.60 & 0.58 & 0.44 & 1.13 & 1.40 \\
\hline $\mathrm{N}$ & 4,734 & 76 & 225 & 481 & 813 & 816 & 626 & 484 & 345 & 237 & 148 & 114 & 88 & 281 \\
\hline
\end{tabular}




\section{Figure 1: Intra-fund performance scores over a fund's life}

This figure shows fund relative deal PME scores over a fund's life in our sample of 10,566 transactions realized by buyout and VC funds. For each deal in a fund, we calculate the difference between the deal PME (from the deal-level monthly gross cash flows before carried interest and fees) and the corresponding fund's PME performance (from aggregated monthly gross cash flows before carried interest and fees of all the deals in the corresponding fund) and divide this by the same fund's PME (y-axis). For example a value of +0.1 for this fund relative deal PME score indicates that the deal PME at hand is $10 \%$ higher than the corresponding fund's overall PME. We group transactions based on the amount of time (in years) that has passed between deal realization and the corresponding fund's first investment and compute the mean of the fund relative deal PME scores each year (x-axis). This figure displays separate curves for the entire sample of 10,566 deals, 5,832 transactions through buyout funds only, and 4,734 transactions through VC funds only.

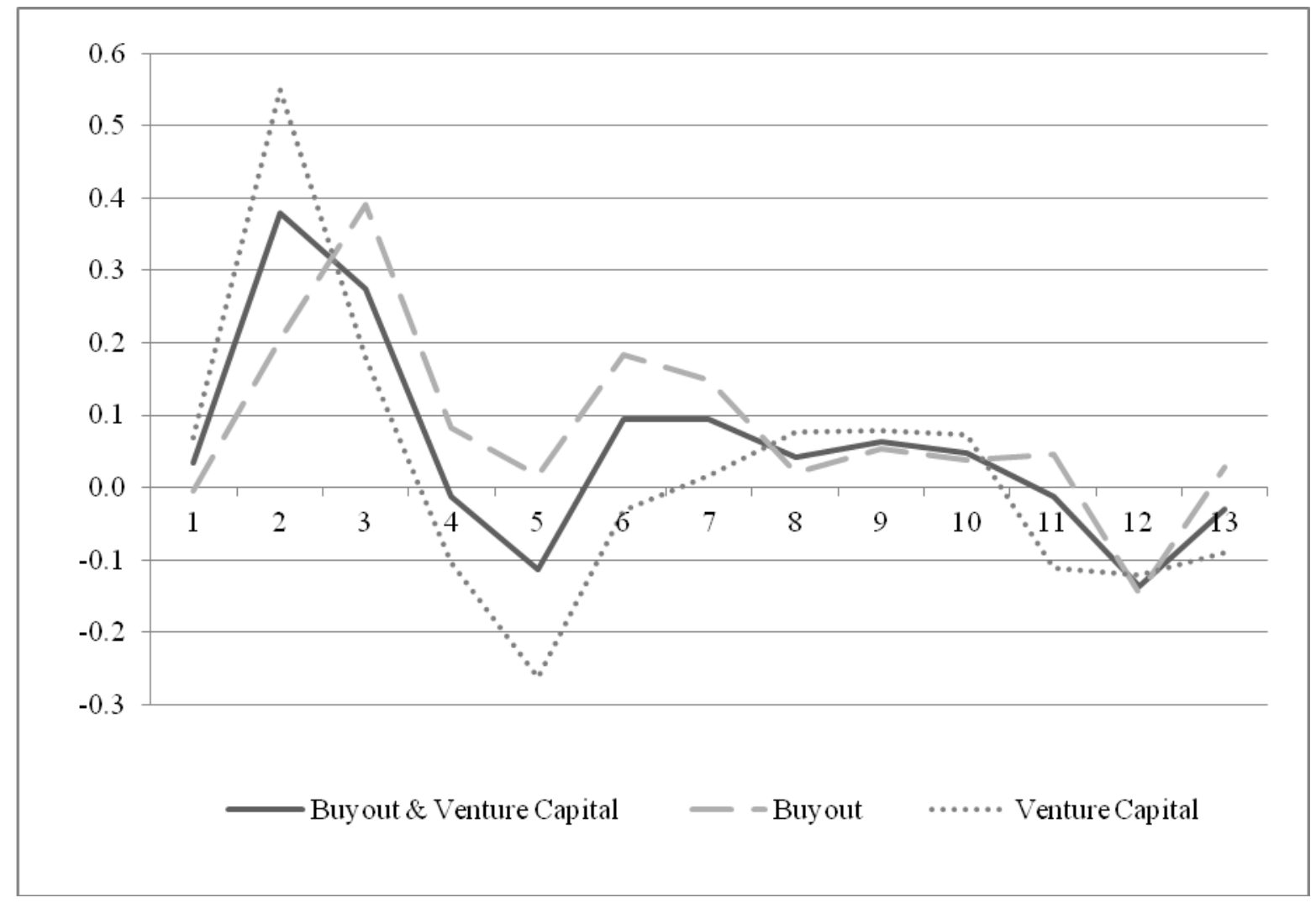




\section{Table 3: Deal performance over a fund's life}

This table presents the results from deal-level Tobit regressions (left censored at -1) of a fund relative deal PME score on fund life year dummies and various other controls. The dependent variable is obtained by dividing the difference between the deal and fund PME by the fund PME. The independent variables are binary fund life variables indicating in which year the deal was realized. The reference category is the third year of the fund's life. Column 1 shows the regression on the entire sample of 10,548 transactions realized by mature buyout and VC funds. In this model we use a dummy variable that equals one if the investment is realized by a VC fund and zero if by a buyout fund. The remaining columns exhibit the results of separate regressions for the buyout fund subsample with 5,821 realized deals (Column 2) and the VC subsample with 4,975 realized deals (Column 3). In models 1 to 3, we control for fund generation, investment size, and holding period. To this end, we include the log of the investing fund's generation, the log of equity investment size in millions of US dollars, and the log of the holding period in months. Further, in all regressions we control for fixed effects related to exit year, industry, and region. Exit year fixed effects cover the time between 1976 and 2010. Industry fixed effects are based on ten basic ICB codes ranging from one (Oil \& Gas) to 9000 (Technology). Regional fixed effects consist of the categories North America, Europe, Asia, and others. The superscripts *, **, and *** denote statistical significance at the $10 \%$, 5\%, and $1 \%$ levels, respectively.

\begin{tabular}{|c|c|c|c|}
\hline \multirow[b]{2}{*}{ VARIABLES } & \multicolumn{3}{|c|}{ (Deal PME-Fund PME) / Fund PME } \\
\hline & (1) & (2) & (3) \\
\hline \multicolumn{4}{|l|}{ Fund Age at Exit (ref: Year 3) } \\
\hline Year 1 & $\begin{array}{c}-0.246^{*} \\
(0.140)\end{array}$ & $\begin{array}{c}-0.357 * * \\
(0.174)\end{array}$ & $\begin{array}{l}-0.263 \\
(0.229)\end{array}$ \\
\hline Year 2 & $\begin{array}{c}0.142 \\
(0.092)\end{array}$ & $\begin{array}{l}-0.101 \\
(0.114)\end{array}$ & $\begin{array}{c}0.353 * * \\
(0.151)\end{array}$ \\
\hline Year 4 & $\begin{array}{c}-0.564 * * * \\
(0.069)\end{array}$ & $\begin{array}{c}-0.437 * * * \\
(0.086)\end{array}$ & $\begin{array}{c}-0.775 * * * \\
(0.114)\end{array}$ \\
\hline Year 5 & $\begin{array}{c}-0.769^{* * *} \\
(0.068)\end{array}$ & $\begin{array}{c}-0.569 * * * \\
(0.084)\end{array}$ & $\begin{array}{c}-1.100 * * * \\
(0.115)\end{array}$ \\
\hline Year 6 & $\begin{array}{c}-0.516^{* * * *} \\
(0.070)\end{array}$ & $\begin{array}{c}-0.397 * * * \\
(0.085)\end{array}$ & $\begin{array}{c}-0.777 * * * \\
(0.121)\end{array}$ \\
\hline Year 7 & $\begin{array}{c}-0.493 * * * \\
(0.074)\end{array}$ & $\begin{array}{c}-0.418 * * * \\
(0.089)\end{array}$ & $\begin{array}{c}-0.694 * * * \\
(0.130)\end{array}$ \\
\hline Year 8 & $\begin{array}{c}-0.555^{* * *} \\
(0.080)\end{array}$ & $\begin{array}{c}-0.528 * * * \\
(0.094)\end{array}$ & $\begin{array}{c}-0.635^{* * *} * \\
(0.142)\end{array}$ \\
\hline Year 9 & $\begin{array}{c}-0.538^{* * * *} \\
(0.086)\end{array}$ & $\begin{array}{c}-0.506^{* * *} \\
(0.100)\end{array}$ & $\begin{array}{c}-0.676 * * * \\
(0.159)\end{array}$ \\
\hline Year 10 & $\begin{array}{c}-0.601 * * * \\
(0.096)\end{array}$ & $\begin{array}{c}-0.543^{* * *} \\
(0.108)\end{array}$ & $\begin{array}{c}-0.713^{* * * *} \\
(0.186)\end{array}$ \\
\hline Year 11 & $\begin{array}{c}-0.669 * * * \\
(0.110)\end{array}$ & $\begin{array}{c}-0.576^{* * *} \\
(0.125)\end{array}$ & $\begin{array}{c}-0.832 * * * \\
(0.206)\end{array}$ \\
\hline Year 12 & $\begin{array}{c}-0.724 * * * \\
(0.125)\end{array}$ & $\begin{array}{c}-0.753^{* * *} \\
(0.145)\end{array}$ & $\begin{array}{c}-0.790 * * * \\
(0.226)\end{array}$ \\
\hline Year 13 & $\begin{array}{c}-0.659 * * * \\
(0.092)\end{array}$ & $\begin{array}{c}-0.549 * * * \\
(0.115)\end{array}$ & $\begin{array}{c}-0.911 * * * \\
(0.151)\end{array}$ \\
\hline Buyout vs. Venture Capital & $\begin{array}{c}-0.292 * * * \\
(0.038)\end{array}$ & & \\
\hline Log Equity Investment & $\begin{array}{c}0.011 \\
(0.015)\end{array}$ & $\begin{array}{l}-0.013 \\
(0.015)\end{array}$ & $\begin{array}{l}0.057^{*} \\
(0.031)\end{array}$ \\
\hline Log Holding Period & $\begin{array}{c}0.230^{* * * *} \\
(0.026)\end{array}$ & $\begin{array}{c}0.157 * * * \\
(0.030)\end{array}$ & $\begin{array}{c}0.350^{* * * *} \\
(0.049)\end{array}$ \\
\hline Fixed effects: Exit year & yes & yes & yes \\
\hline Fixed effects: Industry & yes & yes & yes \\
\hline Fixed effects: Region & yes & yes & yes \\
\hline Constant & $\begin{array}{l}-1.876 \\
(1.578)\end{array}$ & $\begin{array}{l}-1.512 \\
(1.378)\end{array}$ & $\begin{array}{l}-1.383 \\
(1.128)\end{array}$ \\
\hline Observations & 10,548 & 5,821 & 4,727 \\
\hline
\end{tabular}




\section{Table 4: Deal performance and characteristics before and after the final closing of a follow-on fund (bivariate)}

Table 4 displays the differences in performance and characteristics before and after the final closing of the follow-on fund at the deal level, as well as at the fund level. For each fund in our sample, we separate deals by whether they are realized before the final closing of the next fund (pre) or thereafter (post). Panel A exhibits the mean and median times between the first investment of the current fund and the final closing of the follow-on fund (in months). Panel B presents the mean and median deal values within each group (pre vs. post) for the gross PME, a fund relative deal PME score (obtained by dividing the difference between the deal and fund PMEs by the fund PME), equity investment size in millions of US dollars, and the holding period in months. Panel $\mathrm{C}$ reports the synthetic fund-level mean and median values for deals exited in each of the two phases. For each original fund in our sample, we build two synthetic funds: one synthetic fund consisting of all deals realized before the final closing of the follow-on fund (pre) and one containing all deals exited thereafter (post). First, we present the synthetic fund PME and the fund relative synthetic fund PME score (obtained by dividing the difference between the synthetic fund and fund PMEs by the fund PME). Further, Panel C displays the number of exits for three PME performance categories: deals with a PME larger than three, deals with a PME between one and three, and deals with a PME below one. Panel $\mathrm{C}$ also shows the shares of total capital deployed and total distributions (both calculated ex post). Column 1 presents these statistics for all 10,548 fully realized transactions by 702 mature buyout and VC funds, Column 2 presents them for 5,821 deals realized through 452 mature buyout funds, and Column 3 presents the statistics for 4,727 transactions realized by 250 mature VC funds. For each variable in each panel and column we run nonparametric Wilcoxon rank-sum tests. The superscripts $* * *$, and $* * *$ denote statistical significance at the $10 \%, 5 \%$, and $1 \%$ levels, respectively.

\begin{tabular}{|c|c|c|c|c|c|c|c|c|c|c|c|c|c|c|c|}
\hline & \multicolumn{5}{|c|}{ 1. All } & \multicolumn{5}{|c|}{ 2. Buyout only } & \multicolumn{5}{|c|}{ 3. Venture capital only } \\
\hline & \multicolumn{2}{|c|}{ Pre } & \multicolumn{2}{|c|}{ Post } & \multirow{2}{*}{$\begin{array}{c}\text { Rank- } \\
\text { sum }\end{array}$} & \multicolumn{2}{|c|}{ Pre } & \multicolumn{2}{|c|}{ Post } & \multirow{2}{*}{$\begin{array}{l}\text { Rank- } \\
\text { sum }\end{array}$} & \multicolumn{2}{|c|}{ Pre } & \multicolumn{2}{|c|}{ Post } & \multirow{2}{*}{$\begin{array}{c}\text { Rank- } \\
\text { sum }\end{array}$} \\
\hline & Mean & Median & Mean & Median & & Mean & Median & Mean & Median & & Mean & Median & Mean & Median & \\
\hline \multicolumn{16}{|l|}{ Panel A: Fundraising cycle } \\
\hline Duration of stage & 57.48 & 51.92 & & & & 61.24 & 56.92 & & & & 53.49 & 47.90 & & & \\
\hline \multicolumn{16}{|l|}{ Panel B: Deal level } \\
\hline Deal PME & 2.07 & 1.23 & 1.69 & 0.84 & $0.00 * * *$ & 2.27 & 1.44 & 1.90 & 1.22 & $0.01^{* *}$ & 2.13 & 0.91 & 1.45 & 0.33 & $0.00 * * *$ \\
\hline Equity investment & 16.01 & 3.84 & 19.92 & 4.63 & $0.00 * * *$ & 21.84 & 6.03 & 29.40 & 7.93 & $0.08^{*}$ & 6.74 & 2.26 & 9.32 & 3.00 & $0.01^{* * *}$ \\
\hline Holding period & 33.89 & 30.00 & 59.82 & 52.00 & $0.00 * * *$ & 34.00 & 30.00 & 61.50 & 55.00 & $0.00^{* * * *}$ & 33.71 & 30.00 & 57.93 & 48.00 & $0.00 * * *$ \\
\hline $\mathrm{N}$ & 3,606 & & 6,942 & & & 2,141 & & 3,680 & & & 1,465 & & 3,262 & & \\
\hline \multicolumn{16}{|l|}{ Panel C: Synthetic fund level } \\
\hline Synthetic Fund PME & 2.57 & 1.84 & 2.05 & 1.57 & $0.00 * * *$ & 2.27 & 1.94 & 1.97 & 1.63 & $0.00^{* * *}$ & 3.10 & 1.53 & 2.18 & 1.29 & 0.14 \\
\hline (Synth Fund PME - Fund PME)/Fund PME & 0.14 & 0.03 & -0.08 & -0.02 & $0.00 * * *$ & 0.07 & 0.02 & -0.08 & -0.03 & $0.00^{* * * *}$ & 0.26 & 0.04 & -0.08 & -0.01 & $0.00 * * *$ \\
\hline Homeruns $(P M E>3)$ & 1.16 & 1.00 & 1.79 & 1.00 & $0.00 * * *$ & 1.09 & 1.00 & 1.63 & 1.00 & $0.00^{* * *}$ & 1.30 & 1.00 & 2.11 & 1.00 & $0.00 * * *$ \\
\hline Reasonable $(3>P M E>1)$ & 2.02 & 1.00 & 3.33 & 2.00 & $0.00 * * *$ & 2.12 & 1.00 & 3.44 & 2.00 & $0.00^{* * *}$ & 1.82 & 1.00 & 3.12 & 2.00 & $0.00 * * *$ \\
\hline Underperformers $(P M E>3)$ & 2.52 & 1.00 & 5.97 & 3.00 & $0.00 * * *$ & 2.00 & 1.00 & 3.96 & 2.00 & $0.00^{* * *}$ & 3.48 & 2.00 & 9.73 & 6.00 & $0.00 * * *$ \\
\hline Deployed capital share & 0.89 & 0.96 & 0.11 & 0.04 & $0.00 * * *$ & 0.90 & 0.97 & 0.10 & 0.03 & $0.00^{* * * *}$ & 0.88 & 0.93 & 0.12 & 0.07 & $0.00^{* * *}$ \\
\hline Distribution share & 0.32 & 0.22 & 0.68 & 0.78 & $0.00^{* * * *}$ & 0.34 & 0.25 & 0.66 & 0.75 & $0.00^{* * *}$ & 0.28 & 0.15 & 0.72 & 0.85 & $0.00 * * *$ \\
\hline $\mathrm{N}$ & \multicolumn{2}{|l|}{702} & \multicolumn{2}{|l|}{702} & & \multicolumn{2}{|l|}{452} & \multicolumn{2}{|l|}{452} & & \multicolumn{2}{|c|}{250} & \multicolumn{2}{|l|}{250} & \\
\hline
\end{tabular}




\section{Table 5: Performance before and after the final closing of a follow-on fund (multivariate)}

Columns 1 to 3 of this table present the results from the deal-level Tobit regressions (left censored at -1) of a fund's relative deal PME score, obtained by dividing the difference between the deal PME and the PME of the corresponding fund by this fund's PME, on a dummy variable indicating whether a deal was realized before the final closing of the follow-on fund or after, as well as various other controls. The binary independent variable post final closing adopts a value of one if the transaction was realized after the final closing of the follow-on fund and zero otherwise. In models 1 to 3 , we control for fund generation, investment size, and holding period. To this end, we include the log of the investing fund's generation, the log of the equity investment size (by the GP in our data set) in millions of US dollars, and the log of the holding period in months. Further, in all regressions we control for fixed effects related to exit year, industry, and region. Exit year fixed effects cover the period between 1976 and 2010. Industry fixed effects are based on ten basic ICB codes ranging from one (Oil \& Gas) to 9000 (Technology). Regional fixed effects consist of the categories North America, Europe, Asia, and others. In Column 1, using the total sample of buyout and VC funds, we also use a dummy variable that equals one if the investment is carried out by a VC fund and zero if by a buyout fund. Columns 4 to 6 show the results of synthetic fund-level Tobit regressions (left censored at -1 ) with a fund's relative synthetic fund portfolio PME score as the dependent variable. It is obtained by first calculating the PME of the synthetic portfolio of all deals realized before the final closing of a follow-on fund and then by computing the same number for the portfolio of deals within the same fund exited thereafter. Then, in line with the deal-level fund relative PME score, the difference from the total fund PME is divided by the total fund PME. Hence, for each fund in our sample, we obtain two fund relative synthetic fund portfolio PME scores. Further, we include a dummy variable distinguishing the synthetic portfolio of all deals within a fund realized before the final closing of the follow-on fund $(=0)$ and the synthetic portfolio of all deals within a fund realized after a new fund is raised $(=1)$. Fund size growth is a dummy variable obtained by first calculating the growth in fund size between the current fund and the follow-on fund and, second, splitting the sample into low $(=0)$ and high $(=1)$ fund size growth subsamples of equal size. We also include the interaction term of post final closing and fund size growth in regressions 4 to 6 . We control for the size of the current fund (in millions of US dollars), fund vintage year fixed effects, as well as the main industry and region in which the current fund is invested. Column 4 also includes a dummy variable indicating whether the synthetic fund at hand belongs to a buyout fund (=0) or a $\mathrm{VC}$ fund $(=1)$ The superscripts *,**, and $* * *$ denote statistical significance at the $10 \%, 5 \%$, and $1 \%$ levels, respectively.

\begin{tabular}{|c|c|c|c|c|c|c|c|}
\hline \multicolumn{4}{|c|}{ Panel A: (Deal PME - Fund PME) / Fund PME } & \multicolumn{4}{|c|}{ Panel B: (Synth Fund PME - Fund PME) / Fund PME } \\
\hline & All & Buyout only & VC only & & All & Buyout only & vC only \\
\hline VARIABLES & (1) & (2) & (3) & VARIABLES & (4) & (5) & (6) \\
\hline \multirow[t]{3}{*}{ Post final closing } & $\begin{array}{c}-0.335 * * * * \\
(0.037)\end{array}$ & $\begin{array}{c}-0.162 * * * * \\
(0.041)\end{array}$ & $\begin{array}{c}-0.564 * * * * \\
(0.067)\end{array}$ & Post final closing & $\begin{array}{c}-0.126 * * * \\
(0.051)\end{array}$ & $\begin{array}{c}-0.058 \\
(0.053)\end{array}$ & $\begin{array}{c}-0.239 * * \\
(0.103)\end{array}$ \\
\hline & & & & Fund size growth & $\begin{array}{c}0.183 * * * \\
(0.055)\end{array}$ & $\begin{array}{l}0.135 * * \\
(0.057)\end{array}$ & $\begin{array}{c}0.197 \\
(0.122)\end{array}$ \\
\hline & & & & Post final closing* Fund size growth & $\begin{array}{c}-0.217 * * * * \\
(0.072)\end{array}$ & $\begin{array}{c}-0.162^{* * *} \\
(0.074)\end{array}$ & $\begin{array}{c}-0.331 \text { *** } \\
(0.146)\end{array}$ \\
\hline Buyout vs. Venture Capital & $\begin{array}{c}-0.259 * * * \\
(0.038)\end{array}$ & & & Buyout vs. Venture Capital & $\begin{array}{c}0.053 \\
(0.048)\end{array}$ & & \\
\hline Log Equity Investment & $\begin{array}{c}0.013 \\
(0.015)\end{array}$ & $\begin{array}{c}-0.002 \\
(0.015)\end{array}$ & $\begin{array}{c}0.045 \\
(0.031)\end{array}$ & Fund size & $\begin{array}{l}-0.000 \\
(0.000)\end{array}$ & $\begin{array}{c}-0.000 \\
(0.000)\end{array}$ & $\begin{array}{c}-0.000 * \\
(0.000)\end{array}$ \\
\hline Log Holding Period & $\begin{array}{c}0.209 * * * \\
(0.024)\end{array}$ & $\begin{array}{c}0.120 * * * \\
(0.028)\end{array}$ & $\begin{array}{c}0.341 * * * \\
(0.044)\end{array}$ & & & & \\
\hline Fixed effects: Exit year & yes & yes & yes & Fixed effects: Fund vintage year & yes & yes & yes \\
\hline Fixed effects: Industry & yes & yes & yes & Fixed effects: Main industry & yes & yes & yes \\
\hline Fixed effects: Region & yes & yes & yes & Fixed effects: Main region & yes & yes & yes \\
\hline Constant & $\begin{array}{c}-1.634 \\
(1.578)\end{array}$ & $\begin{array}{c}-1.431 \\
(1.376)\end{array}$ & $\begin{array}{c}-1.279 \\
(1.130)\end{array}$ & Constant & $\begin{array}{c}0.102 \\
(0.507)\end{array}$ & $\begin{array}{c}0.761 \\
(0.499)\end{array}$ & $\begin{array}{c}-0.160 \\
(0.710)\end{array}$ \\
\hline Observations & 10,548 & 5,821 & 4,727 & Observations & 1,024 & 657 & 367 \\
\hline
\end{tabular}




\section{Table 6: Before and after the final closing of a follow-on fund over time}

This table presents the results from the deal-level Tobit regressions (left censored at -1) of a fund's relative deal PME score, obtained by dividing the difference between the deal PME and the PME of the corresponding fund by this fund's PME, on a dummy variable indicating whether a deal was realized before the final closing of the follow-on fund or after, as well as various other controls. The binary independent variable post final closing adopts a value of one if the transaction was realized after the final closing of the follow-on fund and zero otherwise. In Columns 1 to 3 we test whether the relation between post final closing and the fund relative deal PME score is moderated by exit market conditions. To construct this market environment measure, we first count the number of global IPOs per exit year and split these years into two categories of equal size: Those years with low numbers of IPOs are given a value of zero and indicate cold exit markets, while those years with high numbers of IPOs are given a value of one and indicate hot exit markets. In a second step, we assign this variable to each realized transaction in our sample, based on exit year. We also include the interaction term of the post final closing and hot exit markets dummies in Columns 1 to 3 . In Columns 4 to 6 we test whether the relation between the dependent and independent variables has changed in recent years. To this end, we include a market maturity dummy indicating whether a deal was realized before $1999(=0)$ or in 1999 or later $(=1)$. We also include the interaction term of the binary variables final closing and market maturity. In models 1 to 6 , we control for fund generation, investment size, and holding period. To this end, we include the log of the investing fund's generation, the log of the equity investment size in millions of US dollars, and the log of the holding period in months. Further, in all regressions we control for fixed effects related to industry and region. Industry fixed effects are based on ten basic ICB codes ranging from one (Oil \& Gas) to 9000 (Technology). Regional fixed effects consist of the categories North America, Europe, Asia, and others. In models 1 and 4, using the total sample of buyout and VC funds, we use a dummy variable that equals one if the investment is carried out by a VC fund and zero if by a buyout fund. The superscripts *, **, and *** denote statistical significance at the $10 \%, 5 \%$, and $1 \%$ levels, respectively.

\begin{tabular}{|c|c|c|c|c|c|c|}
\hline & \multicolumn{6}{|c|}{ (Deal PME - Fund PME) / Fund PME } \\
\hline & \multicolumn{3}{|c|}{ Exit markets (cold vs. hot) } & \multicolumn{3}{|c|}{ Market maturity (pre 1999 vs. post 1998) } \\
\hline & All & Buyout only & VC only & All & Buyout only & VC only \\
\hline VARIABLES & (1) & (2) & (3) & (4) & (5) & (6) \\
\hline Post final closing & $\begin{array}{c}-0.428^{* * *} \\
(0.058)\end{array}$ & $\begin{array}{c}-0.166 * * * \\
(0.064)\end{array}$ & $\begin{array}{c}-0.778 * * * \\
(0.109)\end{array}$ & $\begin{array}{c}-0.113 * * \\
(0.055)\end{array}$ & $\begin{array}{l}-0.065 \\
(0.061)\end{array}$ & $\begin{array}{c}-0.201 * * \\
(0.101)\end{array}$ \\
\hline Hot Exit Markets & $\begin{array}{c}0.198 * * * \\
(0.058)\end{array}$ & $\begin{array}{c}0.076 \\
(0.063)\end{array}$ & $\begin{array}{c}0.364 * * * \\
(0.111)\end{array}$ & & & \\
\hline Post final closing* Hot Exit Markets & $\begin{array}{l}0.116^{*} \\
(0.070)\end{array}$ & $\begin{array}{c}0.005 \\
(0.078)\end{array}$ & $\begin{array}{l}0.242 * \\
(0.130)\end{array}$ & & & \\
\hline Mature Market & & & & $\begin{array}{c}0.165^{* * *} \\
(0.056)\end{array}$ & $\begin{array}{c}0.044 \\
(0.062)\end{array}$ & $\begin{array}{c}0.383^{* * * *} \\
(0.104)\end{array}$ \\
\hline Post final closing* Mature Market & & & & $\begin{array}{c}-0.426^{* * * *} \\
(0.068)\end{array}$ & $\begin{array}{c}-0.163 * * \\
(0.077)\end{array}$ & $\begin{array}{c}-0.801 * * * \\
(0.126)\end{array}$ \\
\hline Buyout vs. Venture Capital & $\begin{array}{c}-0.277^{* * * *} \\
(0.038)\end{array}$ & & & $\begin{array}{c}-0.277 * * * \\
(0.038)\end{array}$ & & \\
\hline Log Equity Investment & $\begin{array}{c}0.012 \\
(0.014)\end{array}$ & $\begin{array}{l}-0.010 \\
(0.014)\end{array}$ & $\begin{array}{c}0.060^{* *} \\
(0.030)\end{array}$ & $\begin{array}{c}0.007 \\
(0.014)\end{array}$ & $\begin{array}{l}-0.007 \\
(0.015)\end{array}$ & $\begin{array}{c}0.032 \\
(0.031)\end{array}$ \\
\hline Log Holding Period & $\begin{array}{c}0.216^{* * * *} \\
(0.024)\end{array}$ & $\begin{array}{c}0.121^{* * * *} \\
(0.027)\end{array}$ & $\begin{array}{c}0.351^{* * *} \\
(0.044)\end{array}$ & $\begin{array}{c}0.225^{* * * *} \\
(0.024)\end{array}$ & $\begin{array}{c}0.123 * * * \\
(0.027)\end{array}$ & $\begin{array}{c}0.386^{* * * *} \\
(0.044)\end{array}$ \\
\hline Fixed effects: Exit year & no & no & no & no & no & no \\
\hline Fixed effects: Industry & yes & yes & yes & yes & yes & yes \\
\hline Fixed effects: Region & yes & yes & yes & yes & yes & yes \\
\hline Constant & $\begin{array}{c}-0.750 * * * \\
(0.261)\end{array}$ & $\begin{array}{c}-0.529 * \\
(0.313)\end{array}$ & $\begin{array}{c}-1.364 * * * \\
(0.438)\end{array}$ & $\begin{array}{c}-0.732 * * * \\
(0.259)\end{array}$ & $\begin{array}{l}-0.508 \\
(0.310)\end{array}$ & $\begin{array}{c}-1.441^{* * * *} \\
(0.436)\end{array}$ \\
\hline Observations & 10,544 & 5,817 & 4,727 & 10,548 & 5,821 & 4,727 \\
\hline
\end{tabular}




\section{Table 7: IPO underpricing before and after the final closing of a follow-on fund (bivariate)}

Table 7 displays the differences in performance and characteristics before and after the final closing of the follow-on funds for 760 IPOs in our sample. These IPOs are a subset of the 10,955 realized deals in our total sample. We separate IPOs by whether they took place before the final closing of the next fund (pre) or thereafter (post). We present the mean and median values for underpricing, firm age at IPO, the holding period at IPO, IPO size, and underwriter reputation. Underpricing is the difference between the closing day bid price and the initial offer price over the first day of trading (in percent). Firm age is the time since the firm was founded at the time of the IPO, in years. Similarly, the holding period at IPO gives the time span between the fund manager's acquisition of the company and the IPO (in years). The IPO size is the sum of gross proceeds in millions of US dollars. Underwriter reputation is a measure introduced by Carter and Manaster (1990; updated on Jay Ritter's webpage), ranging from -9 (low) to +9 (high). Column 1 presents these statistics for all 760 IPOs by buyout and VC funds in our sample. Column 2 displays the results for 257 IPOs sponsored by buyout fund managers in our sample and Column 3 reports the results for 503 IPOs by VC funds. For each variable in Columns 1 to 3 , we run nonparametric Wilcoxon rank-sum tests. The superscripts *,**, and $* * *$ denote statistical significance at the $10 \%$, $5 \%$, and $1 \%$ levels, respectively.

\begin{tabular}{|c|c|c|c|c|c|c|c|c|c|c|c|c|c|c|c|}
\hline & \multicolumn{5}{|c|}{ 1. All } & \multicolumn{5}{|c|}{ 2. Buyout only } & \multicolumn{5}{|c|}{ 3. Venture capital only } \\
\hline & \multicolumn{2}{|c|}{ Pre } & \multicolumn{2}{|c|}{ Post } & \multirow{2}{*}{$\begin{array}{c}\text { Rank- } \\
\text { sum }\end{array}$} & \multicolumn{2}{|c|}{ Pre } & \multicolumn{2}{|c|}{ Post } & \multirow{2}{*}{$\begin{array}{l}\text { Rank- } \\
\text { sum }\end{array}$} & \multicolumn{2}{|c|}{ Pre } & \multicolumn{2}{|c|}{ Post } & \multirow{2}{*}{$\begin{array}{c}\text { Rank- } \\
\text { sum }\end{array}$} \\
\hline & Mean & Median & Mean & Median & & Mean & Median & Mean & Median & & Mean & Median & Mean & Median & \\
\hline Underpricing & 40.34 & 16.30 & 21.67 & 9.40 & $0.00^{* * *}$ & 19.68 & 11.70 & 18.81 & 8.05 & 0.39 & 49.23 & 18.80 & 23.37 & 10.00 & $0.00^{* * *}$ \\
\hline Age at IPO & 9.62 & 5.50 & 12.51 & 7.84 & $0.00^{* * *}$ & 17.07 & 8.12 & 19.53 & 13.58 & $0.01 * *$ & 6.29 & 5.11 & 8.50 & 6.89 & $0.00 * * *$ \\
\hline Holding period at IPO & 26.30 & 21.74 & 62.74 & 58.59 & $0.00^{* * *}$ & 26.66 & 23.93 & 60.71 & 57.31 & $0.00^{* * *}$ & 26.14 & 20.71 & 63.95 & 59.72 & $0.00 * * *$ \\
\hline IPO Size & 88.14 & 49.60 & 95.73 & 59.10 & $0.02^{* *}$ & 165.23 & 90.00 & 151.57 & 101.70 & 0.69 & 54.84 & 42.00 & 62.65 & 48.10 & $0.09^{*}$ \\
\hline Underwriter Reputation & 7.81 & 8.75 & 6.95 & 8.75 & 0.89 & 7.47 & 9.00 & 6.69 & 8.63 & 0.27 & 7.96 & 8.00 & 7.10 & 8.75 & 0.63 \\
\hline $\mathrm{N}$ & 369 & & 391 & & & 111 & & 146 & & & 258 & & 245 & & \\
\hline
\end{tabular}


Table 8: IPO underpricing before and after the final closing of a follow-on fund (multivariate)

This table presents the results from deal-level ordinary least squares regressions of IPO underpricing on a dummy variable indicating whether a deal was realized before the final closing of the follow-on fund or after, as well as various other controls. Underpricing is the difference between the closing day bid price and the initial offer price over the first day of trading (in percent). The binary independent variable post final closing equals one if the transaction was realized after the final closing of the follow-on fund and zero otherwise. Column 1 reports the results for the entire sample of 716 IPOs carried out by buyout and VC funds. In this model we use a dummy variable that equals one if the investment is carried out by a VC fund and zero if by a buyout fund. Column 2 shows the results of a corresponding model for the subsample of 241 IPOs by buyout funds and Column 3 shows those for the subsample of 475 IPOs by VC funds. Columns 4 to 6 differ in that we include the interaction between a binary fund manager reputation variable, fund manager IPO share, and the post final closing dummy. To build this fund manager reputation variable, for each IPO we count the number of global VC-backed IPOs in the three years prior to the corresponding fund's first closing (as reported by Thomson One Banker. We then calculate the market share of the respective fund manager by dividing the number of IPOs backed by the corresponding fund manager by the total number of VC-backed IPOs. In models 1 to 6 , we control for firm age at IPO, IPO size, and underwriter reputation. To this end, we include the log of the firm's age in years, the log of IPO gross proceeds in millions of US dollars, and the underwriter reputation measure introduced by Carter and Manaster (1990; updated on Jay Ritter's webpage) ranging from -9 (low) to +0 (high). Further, in all regressions we control for fixed effects related to IPO year, industry, and region. Exit year fixed effects cover the period between 1981 and 2010. Industry fixed effects are based on ten basic ICB codes ranging from one (Oil \& Gas) to 9000 (Technology). Regional fixed effects consist of the categories North America, Europe, Asia, and others. Standard errors are heteroskedasticity-robust and shown in parentheses. The superscripts *, **, and *** denote statistical significance at the $10 \%, 5 \%$, and $1 \%$ levels, respectively.

\begin{tabular}{|c|c|c|c|c|c|c|}
\hline & \multicolumn{6}{|c|}{ Underprincing (in \%) } \\
\hline & All & Buyout only & VC only & All & Buyout only & VC only \\
\hline VARIABLES & (1) & (2) & (3) & (4) & (5) & (6) \\
\hline Post Final Closing & $\begin{array}{l}-6.205^{*} \\
(3.577)\end{array}$ & $\begin{array}{c}3.009 \\
(5.910)\end{array}$ & $\begin{array}{c}-11.429 * * \\
(4.549)\end{array}$ & $\begin{array}{l}-0.247 \\
(9.311)\end{array}$ & $\begin{array}{c}10.661 \\
(13.641)\end{array}$ & $\begin{array}{c}-7.206 \\
(13.208)\end{array}$ \\
\hline Dummy IPO Share & & & & $\begin{array}{l}-2.634 \\
(6.332)\end{array}$ & $\begin{array}{l}-7.660 \\
(9.243)\end{array}$ & $\begin{array}{c}1.990 \\
(7.766)\end{array}$ \\
\hline Post Final Closing* Dummy IPO Share & & & & $\begin{array}{l}-7.185 \\
(9.717)\end{array}$ & $\begin{array}{l}-10.446 \\
(14.597)\end{array}$ & $\begin{array}{c}-4.991 \\
(13.369)\end{array}$ \\
\hline Buyout vs. Venture Capital & $\begin{array}{c}11.190^{* * * *} \\
(4.217)\end{array}$ & & & $\begin{array}{c}11.536 * * * \\
(4.202)\end{array}$ & & \\
\hline Log Age at IPO & $\begin{array}{c}-5.747 * * * \\
(2.121)\end{array}$ & $\begin{array}{c}-8.162 * * * \\
(2.582)\end{array}$ & $\begin{array}{l}-3.035 \\
(3.859)\end{array}$ & $\begin{array}{c}-5.688^{* * * *} \\
(2.143)\end{array}$ & $\begin{array}{c}-7.763 * * * \\
(2.601)\end{array}$ & $\begin{array}{l}-3.031 \\
(3.899)\end{array}$ \\
\hline Log IPO Size & $\begin{array}{c}13.477 * * * \\
(3.414)\end{array}$ & $\begin{array}{l}-0.210 \\
(4.082)\end{array}$ & $\begin{array}{c}31.419 * * * \\
(5.933)\end{array}$ & $\begin{array}{c}13.616^{* * * *} \\
(3.400)\end{array}$ & $\begin{array}{c}0.185 \\
(3.922)\end{array}$ & $\begin{array}{c}31.364 * * * \\
(5.946)\end{array}$ \\
\hline Underwriter Reputation & $\begin{array}{c}0.483 \\
(0.306)\end{array}$ & $\begin{array}{c}0.329 \\
(0.420)\end{array}$ & $\begin{array}{c}0.295 \\
(0.390)\end{array}$ & $\begin{array}{l}0.512 * \\
(0.304)\end{array}$ & $\begin{array}{c}0.433 \\
(0.415)\end{array}$ & $\begin{array}{c}0.268 \\
(0.388)\end{array}$ \\
\hline Fixed effects: IPO year & yes & yes & yes & yes & yes & yes \\
\hline Fixed effects: Industry & yes & yes & yes & yes & yes & yes \\
\hline Fixed effects: Region & yes & yes & yes & yes & yes & yes \\
\hline Constant & $\begin{array}{c}-96.054 * * * \\
(22.868)\end{array}$ & $\begin{array}{c}3.985 \\
(19.188)\end{array}$ & $\begin{array}{c}-123.870 * * * \\
(19.916)\end{array}$ & $\begin{array}{c}-103.810 * * * \\
(25.086)\end{array}$ & $\begin{array}{c}7.376 \\
(16.262)\end{array}$ & $\begin{array}{c}-127.989 * * * \\
(23.904)\end{array}$ \\
\hline Observations & 716 & 241 & 475 & 716 & 241 & 475 \\
\hline
\end{tabular}

